\title{
A New Generalized High-Frequency Voltage Injection Method and Mirror-Phase Estimation Method for Sensorless Drive of Salient-Pole PMSMs
}

\author{
Shinji Shinnaka Member (Kanagawa University, shinnaka@kanagawa-u.ac.jp)
}

Keywords: high-frequency voltage injection method, speed-varying ellipse, mirror-phase estimation method, sensorless, synchronous motor

This paper proposes a new generalized high-frequency voltage injection method for sensorless drive of salient-pole permanentmagnet synchronous motors. The injected high-frequency voltage has unique spatially-rotating ellipse-shape, whose amplitudes of both major and minor axes vary dependently on the motor speed, and can be designed through selecting a design parameter. The high-frequency current caused by the injected voltage, which has information of rotor phase to be estimated, is speed-independent, i.e. is not affected by the motor speed at all. Consequently, rotor phase can be estimated in wide speed range from zero to the rated speed. Through selection of the design parameter, property of the high-frequency current can be adjusted so that it fits for the associated motor-drive system consisting of a motor and an inverter. As a versatile phase estimation method for estimating rotor phase using the high-frequency current, the "mirror-phase estimation method" is re-constructed and re-proposed.

The high-frequency voltage to be injected by the proposed method is described as

$$
\boldsymbol{v}_{1 h}=V_{h}\left[\begin{array}{c}
\left(1+K \frac{\omega}{\omega_{h}}\right) \cos \omega_{h} t \\
\left(K+\frac{\omega}{\omega_{h}}\right) \sin \omega_{h} t
\end{array}\right] ; \quad \begin{aligned}
& V_{h}=\text { const } \\
& \omega_{h}=\text { const }
\end{aligned}
$$

where $K$ is a design parameter such as

$$
0 \leq K \leq 1 ; K=\text { const. }
$$

The high-frequency current caused by the voltage results in

$$
\boldsymbol{i}_{1 h}=\boldsymbol{i}_{h p}+\boldsymbol{i}_{h n},
$$

where $\boldsymbol{i}_{h p}, \boldsymbol{i}_{h n}$ are positive and negative phase components such as

$$
\begin{aligned}
\boldsymbol{i}_{h p}= & \frac{V_{h}}{2 \omega_{h} L_{d} L_{q}} \\
& *\left[(1+K) L_{i} \boldsymbol{I}-(1-K) L_{m} \boldsymbol{R}\left(2 \theta_{\gamma}\right)\right] \boldsymbol{u}_{p}\left(\omega_{h} t\right) \\
\boldsymbol{i}_{h n}= & \frac{V_{h}}{2 \omega_{h} L_{d} L_{q}} \\
& *\left[(1-K) L_{i} \boldsymbol{I}-(1+K) L_{m} \boldsymbol{R}\left(2 \theta_{\gamma}\right)\right] \boldsymbol{u}_{n}\left(\omega_{h} t\right) .
\end{aligned}
$$

Note that the high-frequency current, which has information of rotor phase $\theta_{\gamma}$ to be estimated, is speed-independent, i.e. is not affected by the motor speed at all.

The current has the following property about component ratio:

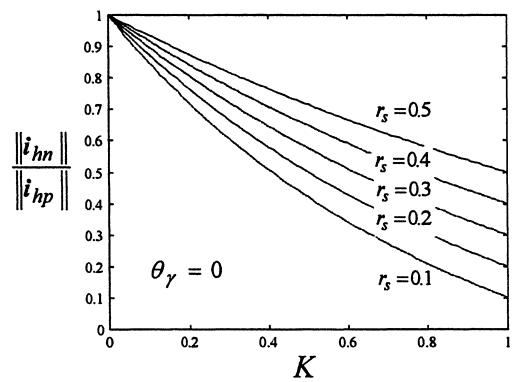

Fig. 1. A relation example between design parameter and positive-negative component ratio

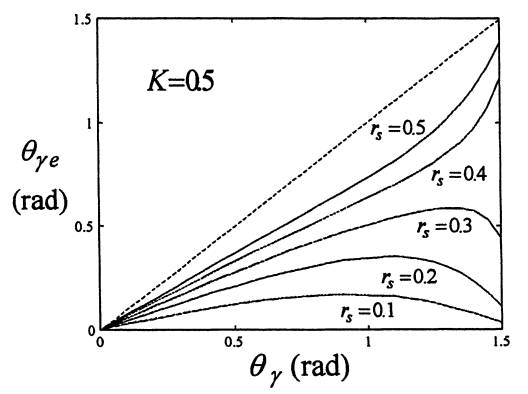

Fig. 2. Relations between rotor phase and major axis phase of high-frequency current ellipse for $K=0.5$

$$
\frac{\left\|\boldsymbol{i}_{h n}\right\|}{\left\|\boldsymbol{i}_{h p}\right\|}=\frac{\left\|(1-K) L_{i} \boldsymbol{I}-(1+K) L_{m} \boldsymbol{R}\left(2 \theta_{\gamma}\right)\right\|}{\left\|(1+K) L_{i} \boldsymbol{I}-(1-K) L_{m} \boldsymbol{R}\left(2 \theta_{\gamma}\right)\right\|}
$$

Note that from viewpoints of $\mathrm{S} / \mathrm{N}$, higher current ratio is desired. Fig. 1 shows a current ratio example for $\theta_{\gamma}=0$ where $r_{s}$ indicates a saliency ratio. As clearly observed. The current ratio can be adjusted through design parameter $K$.

The current has the following property about relation between the rotor phase and the major axis phase of current ellipse:

$$
\theta_{\gamma e}=\frac{1}{2} \tan ^{-1}\left(\frac{\left(1-K^{2}\right) r_{s}^{2} \sin 4 \theta_{\gamma}+2\left(1+K^{2}\right) r_{s} \sin 2 \theta_{\gamma}}{\left(1-K^{2}\right)\left(1+r_{s}^{2} \cos 4 \theta_{\gamma}\right)+2\left(1+K^{2}\right) r_{s} \cos 2 \theta_{\gamma}}\right) .
$$

There is positive correlation between two phases in a region. From viewpoints of rotor phase estimation, wider region is desired. Fig. 2 shows an example of positive correlation region for $K=0.5$. The region, which is function of saliency ratio, can be adjusted through design parameter $K$. 


\title{
突極形永久磁石同期モータセンサレス駆動のための 一般化速応楕円形高周波電圧印加法と鏡相推定法
}

\author{
一一高周波電流楕円長軸追随を目指した沉用位相推定法—
}

\author{
正 員 新中 新二*
}

\author{
A New Generalized High-Frequency Voltage Injection Method and Mirror-Phase \\ Estimation Method for Sensorless Drive of Salient-Pole PMSMs \\ Shinji Shinnaka*, Member
}

\begin{abstract}
This paper proposes a new generalized high-frequency voltage injection method for sensorless drive of salient-pole permanent-magnet synchronous motors. The injected high-frequency voltage has unique spatially-rotating ellipseshape, whose both amplitudes of major and minor axes vary dependently of the motor speed, and can be designed through selecting a design parameter. The high-frequency current caused by the injected voltage, which has information of rotor phase to be estimated, is speed-independent, i.e. is not affected by the motor speed at all. Consequently, rotor phase can be estimated in wide speed range from zero to the rated speed. Through selection of the design parameter, property of the high-frequency current can be adjusted so that it fits for the associated motor-drive system consisting of a motor and an inverter. As a versatile phase estimation method for estimating rotor phase using the high-frequency current, the "mirror-phase estimation method" is re-constructed and re-proposed.
\end{abstract}

キーワード：高周波電圧印加法，速応棈円，鏡相推定法，センサレス，同期モータ

Keywords: high-frequency voltage injection method, speed-varying ellipse, mirror-phase estimation method, sensorless, synchronous motor

\section{1. はじめに}

回転子に永久磁石を有する同期モータである永久磁石同 期モー夕 (permanent-magnet synchronous motor, PMSM) のためのセンサレスベクトル制御法における重要課題の 1 つは, ゼロ速度を含む低速域での適切な回転子位相推定に基 づく, 高トルク発生にある。本課題の現実的な解決方法と して, PMSM の高周波電流に対する突極 (salient pole, SP) 特性を利用した高周波電圧印加法が種々提案され，この実 用化・商用化が電気自動車, ハイブリッド車等への応用を中 心に進められている(11) (14)(22)。この種の応用では, ゼロ速度 での高トルク発生を可能とする位相推定性能と, ゼロ速度 から少なくとも $100(\mathrm{rad} / \mathrm{s})$ 以上の広速領域での安定推定を 可能とする位相推定性能とが同時求められている ${ }^{(11) \sim(14)(22) 。 ~}$

高周波電圧印加法は, PMSM に高周波電圧を印加し, こ の応答である高周波電流を処理し, 高周波電流に含まれる 回転子位相情報を抽出するものである。高周波電圧印加法

\footnotetext{
*神奈川大学工学部電子情報フロンテイア学科

干 221-8686 横浜市神奈川区六角橋 3-27-1

Dept. of Electrical Engineering, Kanagawa University

3-27-1, Rokkakubashi, Kanagawaku, Yokohama 221-8686
}

は，駆動用の電圧・電流情報を必要としないため，駆動用 電圧の $\mathrm{S} / \mathrm{N}$ が著しく低下するゼロ速度においても, 安定な 位相推定が可能である(1) (14)(20) (22)。

高周波電圧印加法の研究開発は, 回転子速度の如何にか かわらず印加高周波電圧の振幅を一定に保つ一定振幅高周

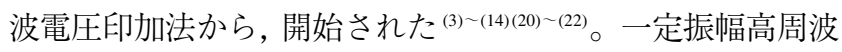
電圧印加法は，矩形状の高周波電圧を印加する方法 ${ }^{(6)(20) ~(22) ~}$ と正弦形状の高周波電圧を印加する方法 ${ }^{(3) \sim(14)}$ に大別され る。後者は, 更に, 印加座標系上で空間的に正回転する正相 (positive phase) あるいは負回転する逆相 (negative phase) の一定振幅高周波電圧を印加する一定真円形と (3) (5)(11) (13), 印加座標系上では空間回転速度ゼロの（以降，ゼロ相（zero phase）と呼称, 本章末尾の注 1 参照) 一定振幅高周波電圧 を印加する一定直線形と ${ }^{(6) \sim(10)(14)}$ に大別される。

一定真円形高周波電圧印加法のための位相推定法として は, 新中の提案による鏡相推定法 ${ }^{(3)(11)}$, Lorenz を中心とする グループの提案によるベクトルヘテロダイン法がある(4)(5)(13)。 一定直線形高周波電圧印加法のための位相推定法としては, 藍原らの提案による FFT 法 ${ }^{(7)}$, Ha, 井手らの提案による 45 度インピーダンス法 ${ }^{(8)}$, Jang らの提案によるスカラーヘテ ロダイン法 ${ }^{(9)(14)}$, 新中, Holtz の提案による高周波電流相関 
信号法 ${ }^{(1)(2)(10)}$ 等がある。

一定振幅高周波電圧印加法は, 印加すべき高周波電圧の振 幅を回転子速度の如何にかかわらず一定に保つ。この反動 として, 回転子位相情報をもつ高周波電流は, 速度への依存 性をもつ。速度依存性のため, 一定振幅高周波電圧印加法に おいては, 印加高周波電圧の真円形・直線形の相違, 位相推 定法の相違はあるが，概して，100(rad/s) 以上を超える中高 速域での推定は困難である ${ }^{(4)}$ (10)。特に，一定直線形高周波 電圧印加法においては，この問題が深刻のようである ${ }^{(6) \sim(10)}$ 。 唯一の例外が，一定真円形高周波電圧印加法と鏡相推定法 との組合せであり ${ }^{(3)}$ ，本組合せでは，100( $\left.\mathrm{rad} / \mathrm{s}\right)$ を優に超え る定格速度までの安定推定が達成されている $(<3 \cdot 2\rangle$ 節末 尾の注 4 参照) (3)(11)。

速度如何にかかわらず，高周波電流から安定的に回転子 位相情報を抽出できるように，高周波電流の速度への非依 存性（以下，速度独立性と略記）を確保しょうとした高周 波電圧印加法が，速応振幅高周波電圧印加法である。本電 圧印加法の研究開発の日は浅く，その 1 つとしての速応楕 円形高周波電圧印加法が，このための位相推定法である高 周波電流相関信号法と共に，新中によって提案されたのは ごく最近である(1)(2)。

本論文は，上記の速応楕円形高周波電圧印加法を特別な 場合として包含する一般化速応楕円形高周波電圧印加法を, 回転子位相推定と直接的な関係をもつ高周波電流に関する 新たな解析と共に，新規に提案するものである。提案の一 般化速応楕円形高周波電圧印加法は，一定真円形高周波電 圧印加法に対して速度独立性を付与した速応真円形高周波 電圧印加法も，特別な場合として包含している。一般性に 富む提案電圧印加法においては，設計者に設計が委ねられ た設計パラメータの選定を通じ，モータ駆動システムの特 性上最適な高周波電圧を印加することができる。また，本 論文では，一般性に富む提案電圧印加法に利用可能な汎用 位相推定法として，鏡相推定法を再提案する。

本論文は, 以下のように構成されている。次の第 2 章で は, 解析の基礎となる PMSM の数学モデル（電気磁気的関 係）の要点を述べると共に，解析に有用な数学的準備を行 う。第 3 章では，速応真円形高周波電圧印加法の提示とこ れにおける高周波電流の挙動解析，速応楕円形高周波電圧 印加法における高周波電流の挙動解析を新規に行う。これ らの解析成果を踏まえ，一般化速応楕円形高周波電圧印加 法の提示とこれにおける高周波電流の挙動解析を新規に行 い，本電圧印加法によれば，モータ駆動システムの特性上 最適な高周波電圧を印加できることを示す。第 4 章では, 第 3 章の解析結果を, 数值実験により定量的に検証確認す る。第 5 章では，先ず，一般化速応楕円形高周波電圧印加 法のための沉用位相推定法として鏡相推定法を再提案し, 次に，一般化速応楕円形高周波電圧印加法と鏡相推定法と を併用したセンサレス駆動制御システムの具体的構成例を 提示する。第 6 章で，本論文を総括する。
（注 1) 印加座標系上で空間回転速度ゼロの 2 相高周波信号 の呼称は，国内外学会，国際会議でも定まっていな い。この種の正弦信号に対して，“pulsating”，“alternating”と言った呼称を使う研究者もいるが(9)(10), 本呼称は「空間回転速度ゼロ」を表現できていない。 本論文では，空間的回転の視点から，正相と逆相と の中間にある空間回転速度ゼロの信号に対し，「ゼ 口相」の呼称を使用する。なお， 2 相高周波信号に 関する本ゼロ相は，3 相信号におけるゼロ相とは全 く別義であるので，注意されたい。

（注 2）本論文では, 混乱の恐れのない限り, 記号 $s$ を微分 演算子 $d / d t$ ，またはラプラス演算子として，断りな く使用する。

\section{2. モータの数学モデルと数学的準備}

図 1 に示した任意の（角）速度 $\omega$ で回転する一般 $\gamma \delta$ 座 標系を考える。主軸（ $\gamma$ 軸）から副軸（ $\delta$ 軸）への回転を正 方向とする。また，突極特性をもつ PMSM(SP-PMSM)の 回転子 $\mathrm{N}$ 極が $\gamma$ 軸に対し，ある瞬時に位相 $\theta_{\gamma}$ をなしてい るものとする。以下に扱う SP-PMSM の物理量を表現した $2 \times 1$ ベクトル信号は, 特に断らない限り, すべて本座標系 上で定義されているものとする。

SP-PMSM の数学モデル（電気磁気的関係）は, $2 \times 2 \mathrm{D}$ 因子 $($ D-matrix) $\boldsymbol{D}(\cdot, \cdot)$ と $2 \times 2$ 鏡行列 (mirror matrix) $\boldsymbol{Q}(\cdot)$ を用いた次式で表現されることが知られている(15)。

[SP-PMSM の数学モデル (電気磁気的部分) $]^{(15)}$ 。
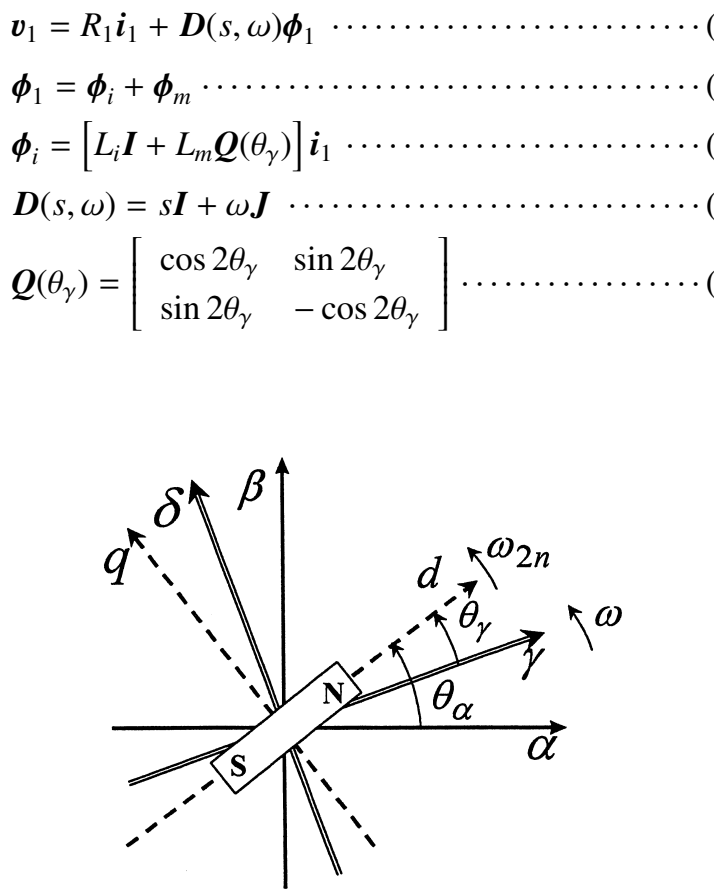

図 1 任意の速度 $\omega$ で回転する一般 $\gamma-\delta$ 座標系上 での回転子 $\mathrm{N}$ 極（突極）位相の関係

Fig. 1. Phase of rotor salient-pole (N pole) in $\gamma-\delta$ general reference frame rotating at arbitrary angular velocity $\omega$. 


$$
\boldsymbol{\phi}_{m}=\Phi\left[\begin{array}{c}
\cos \theta_{\gamma} \\
\sin \theta_{\gamma}
\end{array}\right] ; \quad \Phi=\text { const }
$$$$
s \theta_{\gamma}=\omega_{2 n}-\omega
$$

ここに，2×1ベクトル $v_{1}, i_{1}, \phi_{1}$ は，それぞれ固定子の 電圧, 電流, 磁束を意味している。 $2 \times 1$ ベクトル $\boldsymbol{\phi}_{i}, \boldsymbol{\phi}_{m}$ は固定子磁束 $\phi_{1}$ を構成する成分を示しており， $\phi_{i}$ は固定 子電流 $\boldsymbol{i}_{1}$ によって発生した固定子反作用磁束を， $\phi_{m}$ は回 転子永久磁石に起因する回転子磁束を意味している。I は $2 \times 2$ 単位行列であり， $\boldsymbol{J}$ は次式で定義された $2 \times 2$ 交代行 列である。

$$
\boldsymbol{J}=\left[\begin{array}{cc}
0 & -1 \\
1 & 0
\end{array}\right]
$$

また, $\omega_{2 n}$ は回転子の電気 (角) 速度であり, $R_{1}$ は固定子巻 線の抵抗である。 $L_{i}, L_{m}$ は固定子の同相インダクタンス, 鏡相インダクタンスであり, $\mathrm{d}$ 軸, $\mathrm{q}$ 軸インダクタンスとは 次の関係を有する。

$$
\left[\begin{array}{l}
L_{d} \\
L_{q}
\end{array}\right]=\left[\begin{array}{ll}
1 & 1 \\
1 & -1
\end{array}\right]\left[\begin{array}{l}
L_{i} \\
L_{m}
\end{array}\right] \cdots
$$

(1)〜(9) 式においては, 回転子 $\mathrm{N}$ 極での逆突極特性は, 同相インダクタンスの負性 $L_{m}<0$ で表現されている。

図 1 に明示しているように，SP-PMSM においては，N 極位相 $\theta_{\gamma}$ は逆突極の位相でもある。厳密には, $\mathrm{S}$ 極でも逆 突極が起こり，このため逆突極位相は $\mathrm{N}$ 極に対して $\pi(\mathrm{rad})$ の曖昧性を持つ。しかし，以下では，NS 極の判定は公知の 方法で既に行なわれているものとして ${ }^{(7)(10)(14)} ， \mathrm{~N}$ 極位相と 逆突極位相とは同義の回転子位相として使用する。

\section{3. 速応振幅高周波電圧印加法における電流挙動}

\section{$\langle\mathbf{3} \cdot 1\rangle$ 高周波電流の一般解と数学的準備}

\section{A. 高周波電流の一般解}

高周波電圧印加法は，印加高周波電圧の応答である高周 波電流を処理し，これに含まれる回転子位相情報を抽出す るものである。本事実より明白なように，高周波電流挙動 の解析は, 高周波電流処理法, 位相抽出法の構築において 基盤的重要性を有する。本節では，本認識の下に，高周波 電圧印加により発生する高周波電流の解を，各種高周波電 圧印加法に対応できる一般性のある形で，構築しておく。

モー夕駆動用電圧に高周波電圧を重畳することを考える。 この場合には, 次のように, 固定子の電圧, 電流, 磁束は, 大きくは 2 成分の合成ベクトルとして表現することができ る ${ }^{(3)}$ 。

$$
\left.\begin{array}{l}
\boldsymbol{v}_{1}=\boldsymbol{v}_{1 f}+\boldsymbol{v}_{1 h} \\
\boldsymbol{i}_{1}=\boldsymbol{i}_{1 f}+\boldsymbol{i}_{1 h} \\
\boldsymbol{\phi}_{1}=\boldsymbol{\phi}_{1 f}+\boldsymbol{\phi}_{1 h}
\end{array}\right\}
$$

ここに, 脚符 $f, h$ は, それぞれ駆動周波数 (fundamentaldriving-frequency), 高周波 (high-frequency) の成分である ことを示している。なお，位相推定用に重畳した高周波電
圧の周波数は，次の関係が成立する十分に高いものとする。

$$
\left\|R_{1} i_{1 h}\right\| \ll\left\|[s \boldsymbol{I}+\omega \boldsymbol{J}] \boldsymbol{\phi}_{1 h}\right\| .
$$

(11) 式が成立する場合には，固定子の高周波成分である $\boldsymbol{v}_{1 h}$ ， $\boldsymbol{i}_{1 h}, \boldsymbol{\phi}_{1 h}$ に関しては，(1)〜(10) 式より，以下の関係が成立 する ${ }^{(3)}$ 。

$$
\begin{aligned}
\boldsymbol{v}_{1 h} & =\boldsymbol{D}(s, \omega) \boldsymbol{\phi}_{1 h} \cdots \cdots \\
\boldsymbol{\phi}_{1 h} & =\left[L_{i} \boldsymbol{I}+L_{m} \boldsymbol{Q}\left(\theta_{\gamma}\right)\right] \boldsymbol{i}_{1 h}
\end{aligned}
$$

高周波電圧 $\boldsymbol{v}_{1 h}$ の印加に起因する高周波磁束，高周波電 流は，(12)，(13) 式の逆行列をとることにより，直ちに求 めることができる。すなわち，

$$
\begin{aligned}
\boldsymbol{\phi}_{1 h} & =\boldsymbol{D}^{-1}(s, \omega) \boldsymbol{v}_{1 h} \\
& =\frac{\boldsymbol{D}(s,-\omega)}{s^{2}+\omega^{2}} \boldsymbol{v}_{1 h} \ldots \ldots \ldots \ldots \\
\boldsymbol{i}_{1 h} & =\left[L_{i} \boldsymbol{I}+L_{m} \boldsymbol{Q}\left(\theta_{\gamma}\right)\right]^{-1} \boldsymbol{\phi}_{1 h} \\
& =\frac{1}{L_{d} L_{q}}\left[L_{i} \boldsymbol{I}-L_{m} \boldsymbol{Q}\left(\theta_{\gamma}\right)\right] \boldsymbol{\phi}_{1 h}
\end{aligned}
$$

本論文が提示した (14), (15) 式は，すべての高周波電圧印 加法に適用可能な解である点には，注意されたい。

以下の議論では, 一般性を失うことなく，モー夕はゼロ速 度を含め正方向へ回転するもの，すなわち $\omega_{2 n} \geq 0, \omega \geq 0$ とし, 高周波電圧の一定周波数 $\omega_{h}$ は正とする。本前提は, 印加高周波電圧に起因する高周波磁束, 高周波電流の正相, 逆相成分を区別するためのものである。回転方向あるいは 周波数の符号が反転すると, 正逆相反転が起きることがあ る。本前提は，正逆相反転に起因する記述上の混乱を避け るためのものである。本前提の下で, 正相, 逆相, ゼロ相 の各信号を，各々，脚符 $\mathrm{p}, \mathrm{n}, \mathrm{z}$ を用いて表現する。

\section{B. 数学的準備}

以降の解析における簡略化を考慮し, 若干の数学的準備 を行なう。一定高周波数 $\omega_{h}$ をもつ正相信号, 逆相信号を 意味する $2 \times 1$ 単位信号を，以下のように定義する。

$$
\begin{aligned}
& \boldsymbol{u}_{p}\left(\omega_{h} t\right)=\left[\begin{array}{c}
\sin \omega_{h} t \\
-\cos \omega_{h} t
\end{array}\right] ; \quad \omega_{h}=\text { const } \ldots \ldots \ldots \\
& \boldsymbol{u}_{n}\left(\omega_{h} t\right)=\left[\begin{array}{c}
\sin \omega_{h} t \\
\cos \omega_{h} t
\end{array}\right] ; \quad \omega_{h}=\text { const } \ldots \ldots \ldots
\end{aligned}
$$

また, $2 \times 1$ ベクトル信号に作用するベクトル回転器 $\boldsymbol{R}(\cdot)$ を 以下のように定義する。

$$
\boldsymbol{R}\left(\theta_{\gamma}\right)=\left[\begin{array}{cc}
\cos \theta_{\gamma} & -\sin \theta_{\gamma} \\
\sin \theta_{\gamma} & \cos \theta_{\gamma}
\end{array}\right] .
$$

単位信号, 鏡行列, ベクトル回転器の 3 者の間には, 次 の関係が成立する。

$$
\begin{aligned}
\boldsymbol{Q}\left(\theta_{\gamma}\right) \boldsymbol{u}_{p}\left(\omega_{h} t\right) & =\boldsymbol{Q}\left(\theta_{\gamma}\right) \boldsymbol{Q}(0) \boldsymbol{u}_{n}\left(\omega_{h} t\right) \\
& =\boldsymbol{R}\left(2 \theta_{\gamma}\right) \boldsymbol{u}_{n}\left(\omega_{h} t\right) \cdots \\
\boldsymbol{Q}\left(\theta_{\gamma}\right) \boldsymbol{u}_{n}\left(\omega_{h} t\right) & =\boldsymbol{Q}\left(\theta_{\gamma}\right) \boldsymbol{Q}(0) \boldsymbol{u}_{p}\left(\omega_{h} t\right) \\
& =\boldsymbol{R}\left(2 \theta_{\gamma}\right) \boldsymbol{u}_{p}\left(\omega_{h} t\right) \cdots
\end{aligned}
$$


(18) 式は, 鏡行列 $\boldsymbol{Q}(\cdot)$ が正相，逆相信号に作用する場合に は，これらは，各々逆相，正相信号へ変換されることを意 味する。

以降の解析には，つぎの 2 補題が有用である。

\section{[補題 1 (鏡行列補題)]}

$\gamma \delta$ 座標系上で空間的に回転する $2 \times 1$ ベクトル $\boldsymbol{x}$ が，位 相 $\theta_{\gamma e}$ で長軸をもつ楕円軌道を描くときには, ベクトル $\boldsymbol{x}$ は, (19) 式のように, 位相 $\theta_{\gamma e}$ で鏡相関係にある次の正相 成分 $\boldsymbol{x}_{p}$ と逆相成分 $\boldsymbol{x}_{n}$ の和で表現される。

$$
\begin{aligned}
& \boldsymbol{x}=\boldsymbol{x}_{p}+\boldsymbol{x}_{n} \ldots \ldots \ldots \ldots \ldots \\
& \boldsymbol{x}_{n}=a \boldsymbol{Q}\left(\theta_{\gamma e}\right) \boldsymbol{x}_{p} ; \quad a=\mathrm{const}>0
\end{aligned}
$$

反対に, ベクトル $\boldsymbol{x}$ が (19) 式の性質を持つときには, ベク トル $\boldsymbol{x}$ は，位相 $\theta_{\gamma e}$ で長軸をもつ楕円軌道を描く。

〈証明〉

いま， $\gamma \delta$ 座標系上の $2 \times 1$ ベクトル $\boldsymbol{x}^{\prime}$ が，位相ゼロす なわち $\gamma$ 軸上に長軸をもつ楕円を描くものとする。この場 合，ベクトル $\boldsymbol{x}^{\prime}$ は，明らかに次のように表現される。

$$
\begin{aligned}
& \boldsymbol{x}^{\prime}=\boldsymbol{x}_{p}^{\prime}+\boldsymbol{x}_{n}^{\prime} \ldots \ldots \ldots \ldots \ldots \ldots \\
& \boldsymbol{x}_{n}^{\prime}=a \boldsymbol{Q}(0) \boldsymbol{x}_{p}^{\prime} ; \quad a=\mathrm{const}>0
\end{aligned}
$$

反対に，ベクトル $\boldsymbol{x}^{\prime}$ が(20) 式の性質を持つときには，明ら かに, ベクトル $\boldsymbol{x}^{\prime}$ は $\gamma$ 軸上に長軸をもつ楕円軌道を描く。

信号 $\boldsymbol{x}^{\prime}, \boldsymbol{x}_{p}^{\prime}, \boldsymbol{x}_{n}^{\prime}$ にベクトル回転器 $\boldsymbol{R}(\cdot)$ を作用させた信 号を(21) 式のように定義し，

$$
\left.\begin{array}{l}
\boldsymbol{x}=\boldsymbol{R}\left(\theta_{\gamma}\right) \boldsymbol{x}^{\prime} \\
\boldsymbol{x}_{p}=\boldsymbol{R}\left(\theta_{\gamma e}\right) \boldsymbol{x}_{p}^{\prime} \\
\boldsymbol{x}_{n}=\boldsymbol{R}\left(\theta_{\gamma_{e}}\right) \boldsymbol{x}_{n}^{\prime}
\end{array}\right\}
$$

更に，(22) 式の関係に注意し，

$$
\boldsymbol{Q}\left(\theta_{\gamma e}\right)=\boldsymbol{R}\left(\theta_{\gamma e}\right) \boldsymbol{Q}(0) \boldsymbol{R}\left(-\theta_{\gamma e}\right)
$$

(20) 式の両辺に左からべクトル回転器 $\boldsymbol{R}(\cdot)$ を作用させる と, (19) 式を得る。ベクトル回転器 $\boldsymbol{R}(\cdot)$ は，被作用べクト ルを $\theta_{\gamma e}$ だけ回転させる働きをもつことを考慮するならば, ベクトル $\boldsymbol{x}$ は，位相 $\theta_{\gamma_{e}}$ で長軸をもつ楕円軌道を描く。

\section{[補題 2(鏡相推定補題) ${ }^{(3)}$}

Q.E.D.

(19) 式の性質を持つベクトル $\boldsymbol{x}$ が描く楕円軌道の長軸位 相 $\theta_{\gamma e}$ は, ベクトル $\boldsymbol{x}$ の正相成分と逆相成分に対し, 次の 関係をもつ。

$$
\begin{gathered}
\theta_{\gamma e}=\frac{1}{2} \tan ^{-1}\left(\frac{S_{2 p}}{C_{2 p}}\right) \ldots \ldots \\
{\left[\begin{array}{c}
C_{2 p} \\
S_{2 p}
\end{array}\right]=\left[\begin{array}{ll}
\boldsymbol{x}_{p} & \boldsymbol{J} \boldsymbol{x}_{p}
\end{array}\right] \boldsymbol{x}_{n}}
\end{gathered}
$$

上記鏡相推定補題の証明に関しては，文献(3) を参照さ れたい。 $\langle\mathbf{3 \cdot 2}\rangle$ 速応真円形高周波電圧印加法 $\quad \gamma \delta$ 座標系上で 印加すべき高周波電圧として, 座標系速度 $\omega$ に応じて真円 軌道の半径を変化させる次の信号を，新規に考える。

$$
\boldsymbol{v}_{1 h}=V_{h}\left(1+\frac{\omega}{\omega_{h}}\right)\left[\begin{array}{c}
\cos \omega_{h} t \\
\sin \omega_{h} t
\end{array}\right] ; \quad \begin{aligned}
& V_{h}=\text { const } \\
& \omega_{h}=\text { const }
\end{aligned}
$$

(24) 式において， $\omega$ を常時ゼロに設定する場合には，本 高周波電圧は, 従来の一定真円形となる（本節末尾の注 4 参照) (3) (5)(11) (13)。上記の速応真円形高周波電圧は, 従来の 高周波電圧を改良したものであり，これによれば，速度独 立を確立した高周波電流が得られる。具体的には, 次の定 理が成立する。

\section{[定理 1 (真円電圧定理)］}

(24) 式の真円高周波電圧を印加した場合には，次の高周 波磁束，高周波電流が発生する。

$$
\begin{aligned}
& \boldsymbol{\phi}_{1 h}=\frac{V_{h}}{\omega_{h}} \boldsymbol{u}_{p}\left(\omega_{h} t\right) \cdot \\
& \boldsymbol{i}_{1 h}=\boldsymbol{i}_{h p}+\boldsymbol{i}_{h n} \cdots
\end{aligned}
$$

ここに， $\boldsymbol{i}_{h p}, \boldsymbol{i}_{h n}$ は次の正相，逆相成分である。

$$
\begin{aligned}
\boldsymbol{i}_{h p} & =\frac{L_{i}}{L_{d} L_{q}} \boldsymbol{\phi}_{1 h} \\
& =\frac{L_{i} V_{h}}{\omega_{h} L_{d} L_{q}} \boldsymbol{u}_{p}\left(\omega_{h} t\right) \ldots \ldots . \\
\boldsymbol{i}_{h n} & =\frac{-L_{m}}{L_{d} L_{q}} \boldsymbol{Q}\left(\theta_{\gamma}\right) \boldsymbol{\phi}_{1 h} \\
& =\frac{-L_{m} V_{h}}{\omega_{h} L_{d} L_{q}} \boldsymbol{Q}\left(\theta_{\gamma}\right) \boldsymbol{u}_{p}\left(\omega_{h} t\right) \\
& =\frac{-L_{m} V_{h}}{\omega_{h} L_{d} L_{q}} \boldsymbol{R}\left(2 \theta_{\gamma}\right) \boldsymbol{u}_{n}\left(\omega_{h} t\right) .
\end{aligned}
$$

このとき，正相逆相成分比に関し，次の関係が成立する。

$$
\frac{\left\|\boldsymbol{i}_{h n}\right\|}{\left\|\boldsymbol{i}_{h p}\right\|}=r_{s}
$$

ただし， $r_{s}$ は次式で定義された突極比 (ratio of saliency) で ある。

$$
r_{s}=\frac{-L_{m}}{L_{i}} \geq 0 ; \quad L_{m}<0
$$

〈証明〉

(24) 式を(14) 式に用い，(16) 式を考慮すると，(25) 式を 得る。また，(25) 式を(15) 式に用い，(16)，(18) 式を考慮 すると，(26)，(27) 式を得る。(26), (27) 式の正相性, 逆相 性は, ベクトル回転器 $\boldsymbol{R}(\cdot)$ の性質を考慮するならば，明白 である。

ベクトル回転器 $\boldsymbol{R}(\cdot)$ が直交行列であること, 2 種の単位 ベクトルのノルムが共に 1 でることを考慮すると，(27) 式 より，直ちに(28) 式を得る。

Q.E.D.

(26)，(27) 式に示した高周波電流には，座標系速度 $\omega$ が 出現していない点，すなわち高周波電流の速度独立性が達 成されている点には特に注意されたい。本特性により，回 


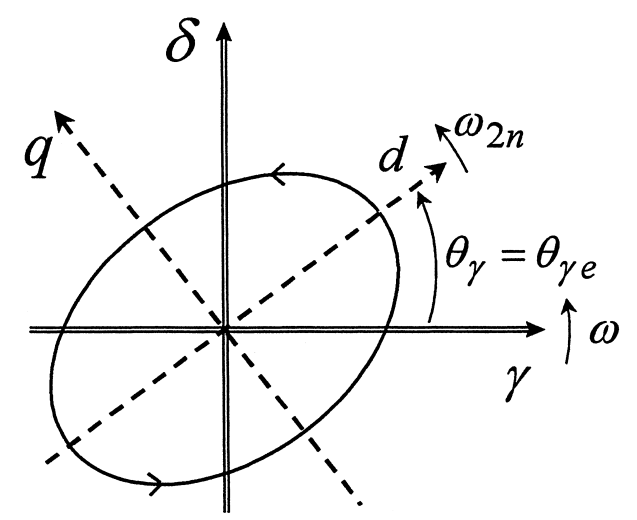

図 2 真円形高周波印加法における電流の挙動

Fig. 2. Behavior of high-frequency current caused by pure-circle high-frequency voltage injection methods.

転速度の如何に問わず高周波電流の振幅が一定に維持され， 高速域においても低速域と同様な回転子位相推定が可能と なる。

(26), (27) 式を補題 1 (鏡行列補題) に適用するならば, 高周波電流 $\boldsymbol{i}_{1 h}$ は, 回転子位相 $\theta_{\gamma}$ に長軸をもつ楕円軌道を 描くことがわかる。このときの楕円の長軸, 短軸は, 各々 次式で与えられる。

$$
\begin{aligned}
\max \left\|\boldsymbol{i}_{1 h}\right\| & =\frac{V_{h}}{\omega_{h} L_{d}} \ldots \ldots \ldots \ldots \ldots \ldots \ldots \ldots \ldots \ldots \ldots \ldots \ldots \ldots \ldots \ldots \ldots \ldots \ldots
\end{aligned}
$$

長軸と短軸の差の $50 \%$ 逆相成分の振幅となる。すなわち,

$$
\left\|\boldsymbol{i}_{h n}\right\|=\frac{\max \left\|\boldsymbol{i}_{1 h}\right\|-\min \left\|\boldsymbol{i}_{1 h}\right\|}{2} .
$$

また, 短軸と長軸の比（以下, 短長軸比と略記）は, イン ダクタンス比となる。すなわち，

$$
\frac{\min \left\|\boldsymbol{i}_{1 h}\right\|}{\max \left\|\boldsymbol{i}_{1 h}\right\|}=\frac{L_{d}}{L_{q}}=\frac{1-r_{s}}{1+r_{s}}<1 .
$$

(30)～(32) 式を踏まえて，高周波電流の棈円軌道を図 2 に描画した。同図に明示しているように, 回転子位相 $\theta_{\gamma}$ と 楕円長軸の位相 $\theta_{\gamma e}$ とは同一である (補題 1, 2 参照)。す なわち, 次の重要な性質が成立している。

$$
\theta_{\gamma e}=\theta_{\gamma} ; \quad\left|\theta_{\gamma}\right|<\frac{\pi}{2}
$$

(33) 式の関係は突極比 $r_{s}$ と無関係である点には，注意され たい（後述の (37) 式参照)。

詳しくはく3・4〉節で説明するが，(28)〜(33) 式の特性が, 速応真円形高周波電圧印加法における回転子位相推定のた めの基本特性となる。

(注3) 高周波電流の正相, 逆相成分である $\boldsymbol{i}_{h p}, \boldsymbol{i}_{h n}$ は, 各々, 同相電流 (in-phase current), 鏡相電流 (mirror-phase current）とも呼ばれる(3)。
(注4)一定真円形高周波電圧印加法における電圧は, 次 式で与えられる(3) (5)(11) (13)。

$$
\boldsymbol{v}_{1 h}=V_{h}\left[\begin{array}{c}
\cos \omega_{h} t \\
\sin \omega_{h} t
\end{array}\right] ; \quad \begin{aligned}
& V_{h}=\text { const } \\
& \omega_{h}=\text { const }
\end{aligned}
$$

本電圧に対応した高周波磁束, 高周波電流は, 定理 1 (真円電圧定理) の援用により, 直ちに以下のよ うに求められる。

$$
\begin{aligned}
& \boldsymbol{\phi}_{1 h}=\frac{V_{h}}{\omega_{h}+\omega} \boldsymbol{u}_{p}\left(\omega_{h} t\right) \\
& \boldsymbol{i}_{1 h}=\boldsymbol{i}_{h p}+\boldsymbol{i}_{h n}
\end{aligned}
$$

ただし，

$$
\begin{aligned}
\boldsymbol{i}_{h p} & =\frac{L_{i}}{L_{d} L_{q}} \boldsymbol{\phi}_{1 h} \\
& =\frac{L_{i} V_{h}}{\left(\omega_{h}+\omega\right) L_{d} L_{q}} \boldsymbol{u}_{p}\left(\omega_{h} t\right) \\
\boldsymbol{i}_{h n} & =\frac{-L_{m}}{L_{d} L_{q}} \boldsymbol{Q}\left(\theta_{\gamma}\right) \boldsymbol{\phi}_{1 h} \\
& =\frac{-L_{m} V_{h}}{\left(\omega_{h}+\omega\right) L_{d} L_{q}} \boldsymbol{Q}\left(\theta_{\gamma}\right) \boldsymbol{u}_{p}\left(\omega_{h} t\right) \\
& =\frac{-L_{m} V_{h}}{\left(\omega_{h}+\omega\right) L_{d} L_{q}} \boldsymbol{R}\left(2 \theta_{\gamma}\right) \boldsymbol{u}_{n}\left(\omega_{h} t\right)
\end{aligned}
$$

上式から明らかなように，一定真円形高周波電圧印 加法においては, 高周波電流の振幅は, 回転子速度 に追随した座標系の速度 $\omega$ に応じて変化する。し かしながら, 幸いにも, 位相推定性能上の重要特性 の 1 つである (33) 式は, すなわち回転子位相と高 周波電流棈円長軸位相との同一特性は, 座標系速 度 $\omega$ に依存することなく, 成立している。この速 度独立性を利用した鏡相推定法は, 広速域の安定 な位相推定に成功している ${ }^{(3)}$ 。

$\langle\mathbf{3} \cdot \mathbf{3}\rangle$ 速応楕円形高周波電圧印加法 $\quad \gamma \delta$ 座標系上で 印加すべき高周波電圧として, 座標系速度 $\omega$ に応じて楕円 軌道の短軸を変化させる次の信号を考える(1)(2)。

$$
\boldsymbol{v}_{1 h}=V_{h}\left[\begin{array}{c}
\cos \omega_{h} t \\
\frac{\omega}{\omega_{h}} \sin \omega_{h} t
\end{array}\right] ; \quad \begin{gathered}
V_{h}=\text { const } \\
\omega_{h}=\text { const }
\end{gathered}
$$

(34) 式の高周波電圧印加に関しては, 高周波電流の速度独 立性を意味する次の定理 2 が成立する ${ }^{(1)(2)}$ 。

[定理 2(楕円電圧定理) ${ }^{(1)(2)}$

(34) 式の楕円形高周波電圧を印加した場合には，次の高 周波磁束，高周波電流が発生する。

$$
\begin{aligned}
& \boldsymbol{\phi}_{1 h}=\frac{V_{h}}{\omega_{h}}\left[\begin{array}{c}
\sin \omega_{h} t \\
0
\end{array}\right] \ldots \ldots \ldots \ldots \ldots \ldots \ldots \ldots \ldots \ldots \\
& \boldsymbol{i}_{1 h}=\frac{V_{h}}{\omega_{h} L_{d} L_{q}}\left[\begin{array}{c}
L_{i}-L_{m} \cos 2 \theta_{\gamma} \\
-L_{m} \sin 2 \theta_{\gamma}
\end{array}\right] \sin \omega_{h} t \ldots \ldots
\end{aligned}
$$

本定理の証明に関しては, 文献 (2) を参照されたい。(36) 式に示した高周波電流には, 座標系速度 $\omega$ が出現していな 


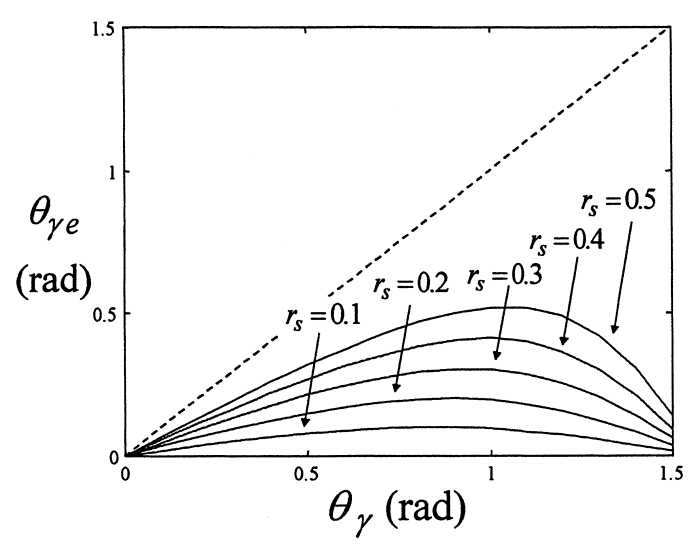

図 3 回転子位相とゼロ相高周波電流位相の関係

Fig. 3. Relations between rotor and zero-phase current phases.

い点，すなわち速度独立性が達成されている点には注意さ れたい。本速度独立性により，高速域においてさえも低速 域と同様な回転子位相推定が可能となる(2)。

(36) 式の高周波電流 $\boldsymbol{i}_{1 h}$ は，ゼ口相成分のみから構成さ れている。従って, 本高周波電流は直線軌道を描く（後掲 の図 4 参照)。本直線軌道の位相 $\theta_{\gamma e}(\gamma$ 軸から評価した位 相）は，(36) 式より次のように求められる。

$$
\begin{aligned}
& \theta_{\gamma e}=\tan ^{-1}\left(\frac{r_{s} \sin 2 \theta_{\gamma}}{1+r_{s} \cos 2 \theta_{\gamma}}\right) . \\
& \left|\theta_{\gamma e}\right| \leq\left|\theta_{\gamma}\right| \ldots \ldots \ldots \ldots \ldots \ldots \ldots \ldots \ldots
\end{aligned}
$$

図 3 に，(37a) 式に従い, 突極比 $r_{s}=0.1 \sim 0.5$ にわたり, 回転子位相 $\theta_{\gamma}$ と直線軌道位相 $\theta_{\gamma e}$ との関係を例示した。な お，参考までに，同図には(33) 式の関係も破線で示してい る。図 3 より明白なように, 高周波電流直線軌道位相 $\theta_{\gamma e}$ は，突極比に依存するが，回転子位相 $\theta_{\gamma}$ が小さい範囲で は，回転子位相と良好な正の相関を有する。例えば，突極 比 $r_{s}=0.2, L_{q} / L_{d}=1.5$ の場合には, $\left|\theta_{\gamma}\right| \leq \pi / 4$ の範囲で 良好な線形性が確認される。詳しくはく3・4〉節で説明する が，この正相関の領域の大小が，回転子位相推定上の重要 な役割を演じることになる（(33) 式参照)。なお，以降で は，正相関が維持される領域を，簡単に，正相関領域と呼 称する。

(35) 式のゼロ相高周波磁束，(36) 式のゼロ相高周波電流 に関しては，次の定理 3 が成立する。

[定理 3 (ゼロ相分離定理) ]

(35) 式のゼロ相高周波磁束は，次の正相，逆相成分から 構成される。

$$
\boldsymbol{\phi}_{1 h}=\frac{V_{h}}{2 \omega_{h}}\left[\boldsymbol{u}_{p}\left(\omega_{h} t\right)+\boldsymbol{u}_{n}\left(\omega_{h} t\right)\right] .
$$

また，(36) 式のゼロ相高周波電流は, 次の正相, 逆相成 分から構成される。

$$
\boldsymbol{i}_{1 h}=\boldsymbol{i}_{h p}+\boldsymbol{i}_{h n}
$$

ただし，

$$
\begin{aligned}
\boldsymbol{i}_{h p} & =\frac{V_{h}}{2 \omega_{h} L_{d} L_{q}}\left[L_{i} \boldsymbol{I}-L_{m} \boldsymbol{R}\left(2 \theta_{\gamma}\right)\right] \boldsymbol{u}_{p}\left(\omega_{h} t\right) \ldots . \\
\boldsymbol{i}_{h n} & =\frac{V_{h}}{2 \omega_{h} L_{d} L_{q}}\left[L_{i} \boldsymbol{I}-L_{m} \boldsymbol{R}\left(2 \theta_{\gamma}\right)\right] \boldsymbol{u}_{n}\left(\omega_{h} t\right) \ldots .
\end{aligned}
$$

このとき，正相逆相成分比に関し，次の関係が成立する。

$$
\frac{\left\|\boldsymbol{i}_{h n}\right\|}{\left\|\boldsymbol{i}_{h p}\right\|}=1
$$

\section{〈証明〉}

(35) 式の右辺は, 次式のように分離展開することができる。

$$
\boldsymbol{\phi}_{1 h}=\frac{V_{h}}{2 \omega_{h}}\left[\left[\begin{array}{c}
\sin \omega_{h} t \\
-\cos \omega_{h} t
\end{array}\right]+\left[\begin{array}{c}
\sin \omega_{h} t \\
\cos \omega_{h} t
\end{array}\right]\right] \cdots \cdots
$$

(42) 式に(16) 式を用いると (38) 式を得る。

(38) 式を(15) 式に用いて, 更に (18) 式の関係を適用す ると，直ちに(39)，(40) 式を得る。(40) 式に扔いては，そ の右辺の $2 \times 2$ 行列の各行及び各列が互いに直交して抢り, ベクトル回転器と同様の構造をしている。従って, 本 $2 \times 2$ 行列を正相，逆相の単位ベクトルに作用させても，作用前 後で信号の正相性, 逆相性は不変である。よって, $\boldsymbol{i}_{h p}, \boldsymbol{i}_{h n}$ は各々正相成分，逆相成分となる。

上記の (40) 式右辺の $2 \times 2$ 行列に関しては, 任意の $2 \times 1$ ベクトル $\boldsymbol{x}$ に対し，次の関係が成立する。

$$
\left\|\left[L_{i} \boldsymbol{I}-L_{m} \boldsymbol{R}\left(2 \theta_{\gamma}\right)\right] \boldsymbol{x}\right\|=\left\|\left[L_{i} \boldsymbol{I}-L_{m} \boldsymbol{R}\left(2 \theta_{\gamma}\right)\right]\right\|\|\boldsymbol{x}\|
$$

(43) 式の関係を(40) 式に適用すると, 直ちに (41) 式を得 る。

Q.E.D.

上記の定理 3 (ゼロ相分離定理) は，直線軌道をもつゼ 口相高周波電流は, 真円軌道を描く正相, 逆相成分の合成 と考えることができることを意味している。補題 1（鏡行 列補題）を参考にするならば，(36) 式の直線軌道をもつ高 周波電流は，次の長軸，短軸をもつ楕円軌道と捉えるのが 合理的である。

$$
\begin{aligned}
\max \left\|\boldsymbol{i}_{1 h}\right\| & =\frac{V_{h}}{\omega_{h} L_{d}} \ldots \ldots \ldots \ldots \ldots \ldots \ldots \ldots \ldots \ldots \ldots \ldots \ldots \ldots \ldots \ldots \ldots \ldots \ldots \ldots \ldots
\end{aligned}
$$

短軸はゼロであるので，短長軸比は，当然ゼロである。す なわち,

$$
\frac{\min \left\|\boldsymbol{i}_{1 h}\right\|}{\max \left\|\boldsymbol{i}_{1 h}\right\|}=0
$$

(44), (45) 式に示した楕円軌道に関する特性は, 突極比 $r_{s}$ と無関係である点には注意されたい $((30) \sim(32)$ 式参照)。

以上の解析結果に従い, (36) 式の高周波電流 $\boldsymbol{i}_{1 h}$ の様子 を図 4 に概略的に示した。同図では，参考までに，(39) (41) 式に従い, 高周波電流を構成する正相, 逆相成分 $\boldsymbol{i}_{h p}$, $\boldsymbol{i}_{h n}$ を破線で示している。

$\langle\mathbf{3} \cdot 4\rangle$ 一般化速応楕円形高周波電圧印加法 速応真 


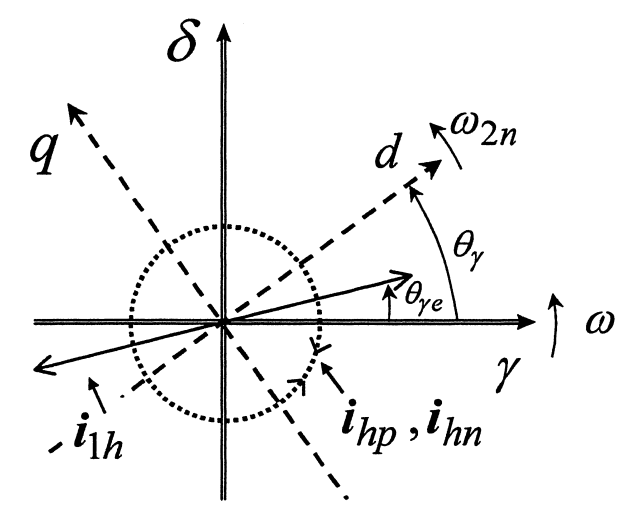

図 4 速応棈円形高周波印加法における電流の挙動

Fig. 4. Behavior of high-frequency current caused by speed-varying- ellipse high-frequency voltage injection method.

円形高周波電圧印加法と速応棈円形高周波電圧印加法の共 通の特長は, 高周波電流に座標系速度 $\omega$ が出現しない点, すなわち高周波電流が速度独立性を有する点にある。本特 性により, 高速域においてさえも, 低速域と同様な回転子 位相推定が可能となる。

両者の相違は, 1) 回転子位相 $\theta_{\gamma}$ と高周波電流楕円の長軸 位相 $\theta_{\gamma e}$ との関係，2) 正相逆相成分比の大小，にある。速 応真円形高周波電圧印加法は, 回転子位相と長軸位相に関 しては，(33) 式が示しているように，全範囲にわたり最良 の同一関係を有する。しかし，正相逆相成分比は，(28) 式 が示しているように, 突極比と同一となる。これに対して, 速応楕円形高周波電圧印加法は, 回転子位相と長軸位相と の正の相関に関しては，(37) 式および図 3 より明白なよう に, 突極比により支配・限定される。しかし, 正相逆相成 分比は，(41) 式が示しているように，最良の1をとる。

本 2 点は, 回転子位相推定に大きな影響を与える重要要 因である。回転子位相推定值が, 衝撃的な外乱等により, 同真值に対して一時的に大きく乘離しても，回転子位相と 高周波電流楕円長軸位相との正相関領域が広く, 乘離回転 子位相が正相関領域に存在すれば，再び位相推定值を同真 值に収敛させることは可能である。しかし，正相関領域が 狭く, 一時的な乘離回転子位相が正相関領域外に出たなら ば，一時的な乘離は推定不能状態に直結する。

位相推定の性能は, 当然のことながら, 正相逆相成分の ノイズに対する $\mathrm{S} / \mathrm{N}$ の影響を受ける。 $\mathrm{S} / \mathrm{N}$ の観点からは, 相対的信号レベルが小さい逆相成分の信号レベルが，推定 性能を支配することになり，実際的には，逆相成分の信号 レベルの向上を図ることが重要である。高周波電圧印加法 が最低限の駆動領域として期待されている，ゼ口速度を含 む低速域は，S/Nの観点からはノイズと等価な影響を及ぼ すインバータ・デッドタイムの影響が最も大きく出る領域 でもある(3)(5)。

上述のように，速応真円形高周波電圧印加法と速応棈円 形高周波電圧印加法は，位相関倸，成分比に扔いて両極端
な長短を見せている。回転子位相推定の実際的な遂行の観 点からは，モー夕突極比，インバータ・デッドタイムなど の駆動システムの特性に応じ，両者の中間的な特性を選定 できる高周波電圧印加法があれば好都合である。本論文で は, この種の新規な高周波電圧印加法として, 座標系速度 $\omega$ に応じて棈円軌道の長短両軸を同時に変化させる次の高 周波電圧を印加する方法を提案する。

$$
\boldsymbol{v}_{1 h}=V_{h}\left[\begin{array}{ll}
\left(1+K \frac{\omega}{\omega_{h}}\right) \cos \omega_{h} t \\
\left(K+\frac{\omega}{\omega_{h}}\right) \sin \omega_{h} t
\end{array}\right] ; \quad \begin{aligned}
& V_{h}=\text { const } \ldots . . . \\
& \omega_{h}=\text { const }
\end{aligned}
$$

ここに, $K$ は, 設計者に選定が委ねられた, 次の性質を持 つ設計パラメータである（本節末尾の注 5 参照）。

$$
0 \leq K \leq 1 ; \quad K=\text { const } .
$$

(46) 式を用いる高周波電圧印加法を, 以降では, 一般化速 応楕円形高周波電圧印加法と呼ぶ。本高周波電圧印加法に 関しては, 高周波電流の速度独立性を示す次の定理 4 が成 立する。

\section{[定理 4 (一般化楕円電圧定理) ]}

(46) 式の速応楕円形高周波電圧を印加した場合には, 次 の高周波磁束，高周波電流が発生する。

$$
\begin{aligned}
\boldsymbol{\phi}_{1 h} & =\frac{V_{h}}{\omega_{h}}\left[\begin{array}{c}
\sin \omega_{h} t \\
-K \cos \omega_{h} t
\end{array}\right] \cdots \\
\boldsymbol{i}_{1 h} & =\boldsymbol{i}_{h p}+\boldsymbol{i}_{h n} \ldots \ldots \ldots \ldots \ldots
\end{aligned}
$$

ここに, $\boldsymbol{i}_{h p}, \boldsymbol{i}_{h n}$ は次の正相, 逆相成分である。

$$
\begin{aligned}
\boldsymbol{i}_{h p} & =\frac{V_{h}}{2 \omega_{h} L_{d} L_{q}} \\
& *\left[(1+K) L_{i} \boldsymbol{I}-(1-K) L_{m} \boldsymbol{R}\left(2 \theta_{\gamma}\right)\right] \boldsymbol{u}_{p}\left(\omega_{h} t\right) \\
& \ldots \ldots \ldots \ldots \ldots \ldots \ldots \ldots \ldots \\
\boldsymbol{i}_{h n} & =\frac{V_{h}}{2 \omega_{h} L_{d} L_{q}} \\
& *\left[(1-K) L_{i} \boldsymbol{I}-(1+K) L_{m} \boldsymbol{R}\left(2 \theta_{\gamma}\right)\right] \boldsymbol{u}_{n}\left(\omega_{h} t\right)
\end{aligned}
$$

このとき，正相逆相成分比に関し，次の関倸が成立する。

$$
\frac{\left\|\boldsymbol{i}_{h n}\right\|}{\left\|\boldsymbol{i}_{h p}\right\|}=\frac{\left\|(1-K) L_{i} \boldsymbol{I}-(1+K) L_{m} \boldsymbol{R}\left(2 \theta_{\gamma}\right)\right\|}{\left\|(1+K) L_{i} \boldsymbol{I}-(1-K) L_{m} \boldsymbol{R}\left(2 \theta_{\gamma}\right)\right\|} \ldots \ldots
$$
ただし，

$$
\begin{aligned}
\left\|(1+K) L_{i} \boldsymbol{I}-(1-K) L_{m} \boldsymbol{R}\left(2 \theta_{\gamma}\right)\right\|^{2} \\
=\left(L_{i}^{2}+L_{m}^{2}-2 L_{i} L_{m} \cos 2 \theta_{\gamma}\right)+2 K\left(L_{i}^{2}-L_{m}^{2}\right) \\
\quad+K^{2}\left(L_{i}^{2}+L_{m}^{2}+2 L_{i} L_{m} \cos 2 \theta_{\gamma}\right) \ldots \ldots \ldots . \\
\left\|(1-K) L_{i} \boldsymbol{I}-(1+K) L_{m} \boldsymbol{R}\left(2 \theta_{\gamma}\right)\right\|^{2} \\
=\left(L_{i}^{2}+L_{m}^{2}-2 L_{i} L_{m} \cos 2 \theta_{\gamma}\right)-2 K\left(L_{i}^{2}-L_{m}^{2}\right) \\
\quad+K^{2}\left(L_{i}^{2}+L_{m}^{2}+2 L_{i} L_{m} \cos 2 \theta_{\gamma}\right) \ldots \ldots \ldots
\end{aligned}
$$


〈証明〉

(46) 式の高周波電圧は, 次式のように分離展開できる。

$$
\begin{aligned}
\boldsymbol{v}_{1 h}= & K V_{h}\left(1+\frac{\omega}{\omega_{h}}\right)\left[\begin{array}{c}
\cos \omega_{h} t \\
\sin \omega_{h} t
\end{array}\right] \\
& +(1-K) V_{h}\left[\begin{array}{c}
\cos \omega_{h} t \\
\frac{\omega}{\omega_{h}} \sin \omega_{h} t
\end{array}\right]
\end{aligned}
$$

(53) 式は，(24) 式，(34) 式の高周波電圧に, 各々重み $K$, $(1-K)$ をつけて加法合成したものと同一である。(53) 式 の高周波電圧に対応した高周波磁束，高周波電流は，(53) 式を(14)，(15) 式に用いると，得られる。これは，(24) 式, (34) 式の高周波電圧に対応した高周波磁束，高周波電流（定 理 1 (真円電圧定理), 定理 3 (ゼロ相分離定理) 参照)に 同一の重み $K,(1-K)$ をつけ加法合成したものと同一とな る。本認識と定理 $1 ， 3$ とにより，直ちに，(48)〜 (50) 式が 得られる。

(50) 式においては，その右辺の $2 \times 2$ 行列の各行及び各 列が互いに直交しており, ベクトル回転器と同様の構造を している。従って, 本 $2 \times 2$ 行列を正相, 逆相の単位べク トルに作用させても，作用前後で信号の正相性，逆相性は 不変である。よって, $i_{h p}, i_{h n}$ は各々正相成分, 逆相成分と なる。

(50) 式右辺の $2 \times 2$ 行列の上記直交性より，同行列の列 ベクトルノルムあるいは行ベクトルノルムが, 同行列のノ ルムと同一となる。また，同行列が作用する 2 個の $2 \times 1$ ベクトルは共にノルム 1 の単位ベクトルである。本事実を (50) 式に適用しノルム評価を行うと，(51)，(52) 式を得る。

Q.E.D.

一般化速応楕円形高周波電圧印加法に関しては，先ず， (50) 式が明示しているように，高周波電流の速度独立性を 達成している点に，注意されたい。

次に，高周波電流の正相逆相成分比であるが，これは， (51)，(52) 式より明らかなように，厳密には回転子位相 $\theta_{\gamma}$ の関数となる。しかし，(52) 式の 2 式の比較より明白なよ うに，相対比である成分比を支配するのは同式右辺第 2 項 であり，本項は回転子位相と無関係である。この点を考慮 するならば， $\theta_{\gamma}=0$ における代表的な成分比の把握が有用 である。 $\theta_{\gamma}=0$ の条件を(51)，(52) 式に適用すると，簡明 な次式を得る。

$$
\begin{aligned}
\frac{\left\|\boldsymbol{i}_{h n}\right\|}{\left\|\boldsymbol{i}_{h p}\right\|} & =\frac{L_{q}-K L_{d}}{L_{q}+K L_{d}} \\
& =\frac{\left(1+r_{s}\right)-K\left(1-r_{s}\right)}{\left(1+r_{s}\right)+K\left(1-r_{s}\right)} ; \quad \theta_{\gamma}=0 \ldots \ldots \ldots
\end{aligned}
$$

本条件下の楕円の短長軸比は，(54) 式を補題 1（鏡行列補

題）に適用することにより，次のように求められる。

$$
\begin{aligned}
\frac{\min \left\|\boldsymbol{i}_{1 h}\right\|}{\max \left\|\boldsymbol{i}_{1 h}\right\|} & =\frac{\left\|\boldsymbol{i}_{h p}\right\|-\left\|\boldsymbol{i}_{h n}\right\|}{\left\|\boldsymbol{i}_{h p}\right\|+\left\|\boldsymbol{i}_{h n}\right\|} \\
& =K \frac{L_{d}}{L_{q}}=K \frac{\left(1-r_{s}\right)}{\left(1+r_{s}\right)} ; \quad \theta_{\gamma}=0 \ldots \ldots
\end{aligned}
$$

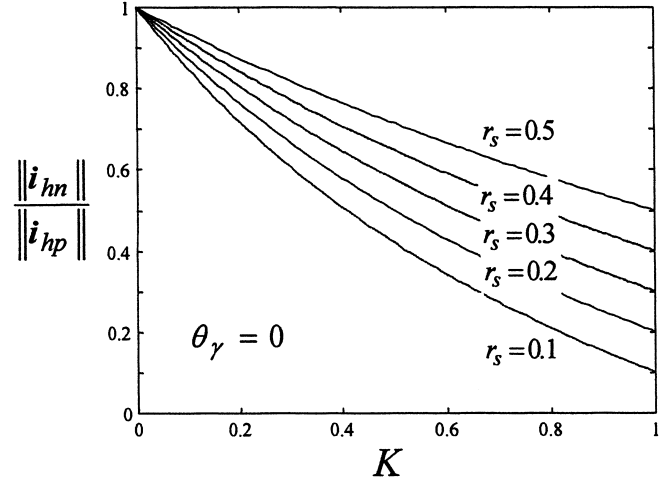

(a)

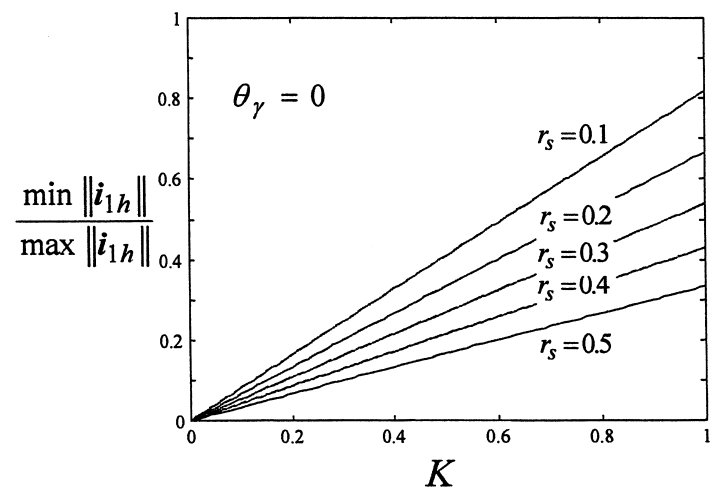

(a)

図 5 設計パラメータ $K$ と正相逆相性分比と短長 軸比の 1 関係例

Fig. 5. An example of positive-negative component ratio and minor/major-axis ratio vs. frequency-ratio.

図 5(a)に， $\theta_{\gamma}=0$ を条件とした(54) 式に基づき，突極比 $r_{s}=0.1 \sim 0.5$ にわたり，設計パラメータ $K$ と正相逆相成分 比との関係を例示した。同図より明白なように，設計パラ メータ $K$ と正相逆相成分比とは，概ね比例的関係があり， 設計パラメータを用いて，正相逆相成分比を自在に指定で きることがわかる。例えば，突極比 $r_{s}=0.2 ， L_{q} / L_{d}=1.5$ のモータに対し $K=0.5$ を選定する場合には, 正相逆相成 分比として約 0.5 を得る。速応真円形高周波電圧印加法に おける正相逆相成分比 0.2 に比較すると，約 $250 \%$ の改善 である（(28) 式参照)。

正相逆相成分比の変更は, 高周波電流楕円軌道の変更を 意味する。具体的には, 設計パラメータ $K$ の指定は, 高周 波電流楕円軌道の短長軸比を変更することになる。図 5(b) は， $\theta_{\gamma}=0$ を条件とした (55) 式に基づきこの様子を示した ものである。

一般化速応楕円形高周波電圧印加法のもう一つの特徵は, 回転子位相 $\theta_{\gamma}$ と高周波電流楕円の長軸位相 $\theta_{\gamma e}$ との正相関 の改善にある。定理 4 (一般化楕円電圧定理) の結論を補 題 2 (鏡相推定補題) に適用すると, 正相関領域を解明す る次の定理 5 を得ることができる。

[定理 5 (長軸位相定理)]

回転子位相が $\theta_{\gamma}$ のとき，(49)，(50) 式の高周波電流が描 く楕円の長軸位相 $\theta_{\gamma e}$ は, 次式で与えられる。 


$$
\begin{aligned}
& \theta_{\gamma e}= \\
& \frac{1}{2} \tan ^{-1}\left(\frac{\left(1-K^{2}\right) r_{s}^{2} \sin 4 \theta_{\gamma}+2\left(1+K^{2}\right) r_{s} \sin 2 \theta_{\gamma}}{\left(1-K^{2}\right)\left(1+r_{s}^{2} \cos 4 \theta_{\gamma}\right)+2\left(1+K^{2}\right) r_{s} \cos 2 \theta_{\gamma}}\right)
\end{aligned}
$$

\section{〈証明〉}

補題 2 (鏡相推定補題) の (23b) 式に, 正相信号, 逆相信 号として (50) 式を適用すると次式を得る。

$$
\begin{aligned}
{\left[\begin{array}{c}
C_{2 p} \\
S_{2 p}
\end{array}\right]=\left[\begin{array}{ll}
\boldsymbol{i}_{h p} & \boldsymbol{J} \boldsymbol{i}_{h p}
\end{array}\right] \boldsymbol{i}_{h n} } \\
=\left(\frac{V_{h}}{2 \omega_{h} L_{d} L_{q}}\right)^{2}\left[(1+K) L_{i} \boldsymbol{I}-(1-K) L_{m} \boldsymbol{R}\left(2 \theta_{\gamma}\right)\right] \\
\quad *\left[\boldsymbol{u}_{p}\left(\omega_{h} t\right) \quad \boldsymbol{J} \boldsymbol{u}_{p}\left(\omega_{h} t\right)\right] \\
\quad *\left[(1-K) L_{i} \boldsymbol{I}-(1+K) L_{m} \boldsymbol{R}\left(2 \theta_{\gamma}\right)\right] \boldsymbol{u}_{n}\left(\omega_{h} t\right)
\end{aligned}
$$

ここで，次の性質に注意すると，

$$
\begin{array}{r}
{\left[\begin{array}{ll}
\boldsymbol{u}_{p}\left(\omega_{h} t\right) & \boldsymbol{J} \boldsymbol{u}_{p}\left(\omega_{h} t\right)
\end{array}\right]=\left[\begin{array}{cc}
\sin \omega_{h} t & \cos \omega_{h} t \\
-\cos \omega_{h} t & \sin \omega_{h} t
\end{array}\right]} \\
\ldots \ldots \ldots \ldots \ldots \ldots \ldots \\
{\left[\begin{array}{ll}
\boldsymbol{u}_{p}\left(\omega_{h} t\right) & \boldsymbol{J} \boldsymbol{u}_{p}\left(\omega_{h} t\right)
\end{array}\right] \boldsymbol{u}_{h}\left(\omega_{h} t\right)=\left[\begin{array}{l}
1 \\
0
\end{array}\right] \ldots \ldots \ldots}
\end{array}
$$

(57) 式は，次式のように整理することができる。

$$
\begin{aligned}
{\left[\begin{array}{c}
C_{2 p} \\
S_{2 p}
\end{array}\right]=} & \left(\frac{V_{h}}{2 \omega_{h} L_{d} L_{q}}\right)^{2}\left[(1+K) L_{i} \boldsymbol{I}-(1-K) L_{m} \boldsymbol{R}\left(2 \theta_{\gamma}\right)\right] \\
& *\left[(1-K) L_{i} \boldsymbol{I}-(1+K) L_{m} \boldsymbol{R}\left(2 \theta_{\gamma}\right)\right]\left[\begin{array}{l}
1 \\
0
\end{array}\right] \\
= & \left(\frac{V_{h}}{2 \omega_{h} L_{d} L_{q}}\right)^{2} \\
& *\left[\begin{array}{c}
\left(1-K^{2}\right)\left(1+r_{s}^{2} \cos 4 \theta_{\gamma}\right)+2\left(1+K^{2}\right) r_{s} \cos 2 \theta_{\gamma} \\
\left(1-K^{2}\right) r_{s}^{2} \sin 4 \theta_{\gamma}+2\left(1+K^{2}\right) r_{s} \sin 2 \theta_{\gamma}
\end{array}\right]
\end{aligned}
$$

(60) 式を補題 2（鏡相推定補題）の (23a) 式に適用すると, (56) 式を得る。

Q.E.D.

当然のことながら, 定理 5 (長軸位相定理) の (56) 式は, $K=1$ と選定する場合には (33) 式に, $K=0$ と選定する場 合には (37) 式に, 帰着される。(56) 式は, 次式のように書 き直すこともできる。

$\theta_{\gamma e}=$

$-\frac{1}{2} \cot ^{-1}\left(\frac{\left(1-K^{2}\right) r_{s}^{2} \sin 4 \theta_{\gamma}+2\left(1+K^{2}\right) r_{s} \sin 2 \theta_{\gamma}}{\left(1-K^{2}\right)\left(1+r_{s}^{2} \cos 4 \theta_{\gamma}\right)+2\left(1+K^{2}\right) r_{s} \cos 2 \theta_{\gamma}}\right)$

$+\operatorname{sgn}\left(\theta_{\gamma}\right) \frac{\pi}{4}$

ここに, $\operatorname{sgn}(\cdot)$ は符号関数（シグナム関数）を意味する。 図 6 に，(61) 式に基づき， $K=0.5$ の場合について，突極 比 $r_{s}=0.1 \sim 0.5$ にわたり, 回転子位相 $\theta_{\gamma}$ と直線軌道位相

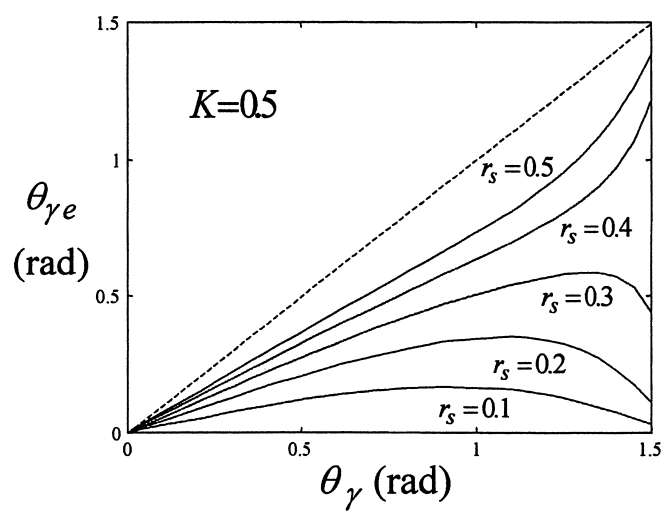

図 6 回転子位相と高周波電流楕円長軸位相の関倸 Fig. 6. Relations between rotor phase and major axis phase of high-frequency current ellipse.

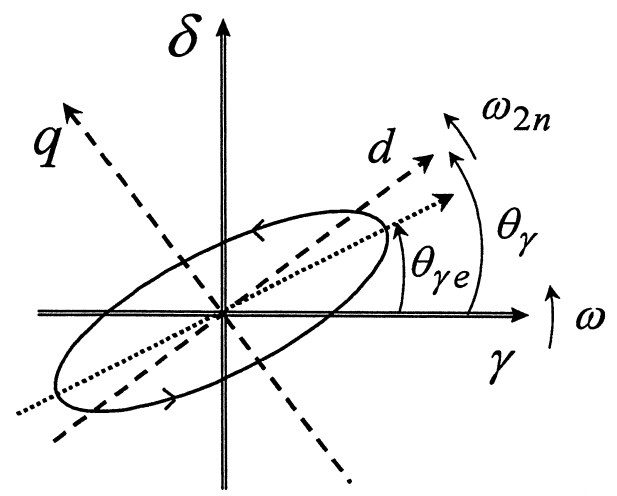

図 7 一般化速応棈円形高周波印加法における電 流の挙動

Fig. 7. Behavior of high-frequency current caused by generalized speed-varying- ellipse high-frequency voltage injection method.

$\theta_{\gamma e}$ との相関特性を例示した。なお，同図には，参考まで に，(33) 式の関係も破線で示している。

一般化速応楕円形高周波電圧印法に扔いては，速応楕円 形高周波電圧印法を基準とするならば, 図 6 と図 3 との比 較より明白なように，正相関領域は，大幅に拡張されてい る。突極比 $r_{s}$ が 0.35 以上の場合には, 全領域で正の相関が 実質達成され，比確的小さい突極比 $r_{s}=0.2, L_{q} / L_{d}=1.5$ の場合でさえ, 正相関領域は $\left|\theta_{\gamma}\right| \leq 1.2$ 程度まで拡張され ている。

定理 4 (一般化楕円電圧定理), 定理 5 (長軸位相定理) の解析結果に基づき，一般化速応楕円形高周波電圧印法に おける高周波電流挙動の概要を, 図 7 に例示した。本高周 波電圧印法における高周波電流の挙動は, 速応真円形高周 波電圧印加法と速応楕円形高周波電圧印法との中間的な挙 動を示す。本高周波電圧印加法による高周波電流では, 速 応真円形高周波電圧印加法を基準とするならば，逆相成分 が相対的に増加する。このため, 高周波電流軌道の楕円は, より扁平な形状を示す (図 2 参照)。一方, 楕円長軸位相 は, もはや (33) 式の理想的特性は示さなくなり, 速応楕円 
形高周波電圧印加法の特徴である (37b) 式の特性を示し始 め，楕円長軸は $\gamma$ 軸よりとなる。しかし，楕円長軸の位相 は (37a) 式より良好な正相関を示すようになる。

（注 5）(47) 式では，設計パラメータ $K$ に対して非負の条件 を付したが，形式的に本条件を取り除くことができ る。(46) 式から理解されるように，高周波 $\omega_{h}$ に対 し負の設計パラメータ $K$ を採用するということは, 高周波 $-\omega_{h}$ に対し正の設計パラメータ $|K|$ を採用す ることと等価である。換言するならば，(47)式のよ うに設計パラメータ $K$ に対して非負の条件を付すこ とにより，一般性を失うことはない。

\section{4. 解析結果の検証}

本章では, 第 3 章の解析結果の正等性を, 数值実験を通 じ定量的に検証する。回転子位相推定の観点から，特に重 要な解析結果は, 次の 3 点である。

(a) 回転子位相情報を含む高周波電流の速度独立性。

(b) 回転子位相と高周波電流楕円長軸位相との正相関。

(c) 高周波電流の構成成分と正相逆相成分比。

検証のための供試モー夕の特性は, 文献 (2), (3) と同一の 表 1 とした。本供試モータの突極比は, 次の通りである。

表 1 供試モー夕の特性

Table 1. Characteristics of test motor.

\begin{tabular}{|l|l|l|l|}
\hline$R_{1}$ & $2.259(\Omega)$ & rated power & $400(\mathrm{~W})$ \\
\hline$L_{i}$ & $0.02662(\mathrm{H})$ & rated torque & $2.2(\mathrm{Nm})$ \\
\hline$L_{m}$ & $-0.00588(\mathrm{H})$ & rated speed & $183(\mathrm{rad} / \mathrm{s})$ \\
\hline$\Phi$ & $0.2165(\mathrm{~V} \mathrm{~s} / \mathrm{rad})$ & rated current & $1.7(\mathrm{~A}, \mathrm{rms})$ \\
\hline$N_{p}$ & 3 & rated voltage & $163(\mathrm{~V}, \mathrm{rms})$ \\
\hline
\end{tabular}

$$
r_{s}=\frac{-L_{m}}{L_{i}} \approx 0.22
$$

表 1 のパラメータを用いて, 文献(18)の方法で, モータシ ミュレータを構成し，高周波電圧を印加した。この際，高 周波電圧の振幅, 周波数は, 以下のように文献(2), (3) と同 一とした。

$$
\left.\begin{array}{rl}
V_{h} & =23(\mathrm{~V}) \\
\omega_{h} & =800 \cdot \pi(\mathrm{rad} / \mathrm{s})
\end{array}\right\} \cdots
$$

このときの回転子の位相，速度，座標系の速度は，検証が 行い易いように，以下のように常時一定に保った。

$$
\left.\begin{array}{l}
\theta_{\gamma}=\frac{\pi}{4}(\mathrm{rad}) \\
\omega_{2 \mathrm{n}}=\omega=\mathrm{const}
\end{array}\right\}
$$

高周波電流に含まれる正相成分，逆相成分の抽出には，D 因子フィルタを用いた ${ }^{(16)(17)}$ 。

\section{A. 速度独立性の検証}

一般化速応棈円形高周波電圧印加法における高周波電圧 (46) 式を, 設計パラメータを $K=0.5$ と選定して, 印加 した。このときのモー夕速度, 座標系の速度は, ゼロ速度 $\omega_{2 \mathrm{n}}=\omega=0(\mathrm{rad} / \mathrm{s})$ と定格速度 $\omega_{2 \mathrm{n}}=\omega=540(\mathrm{rad} / \mathrm{s})$ と した。図 8 にゼロ速度の応答を, 図 9 に定格速度の応答を 示す。各図は，左端より，順次，高周波電流，正相成分， 逆相成分である。なお, 図には, 参考までに, 回転子位相 $\theta_{\gamma}=\pi / 4(\mathrm{rad})$ を破線で示した。

図 8, 図 9 の比較より明白なように, 両図の電流に有意の 違いはない。これら応答は，一般化速応楕円形高周波電圧 印加法における高周波電流は速度独立性を有すること，ひ いては解析結果の正等性を裏付けるものである。
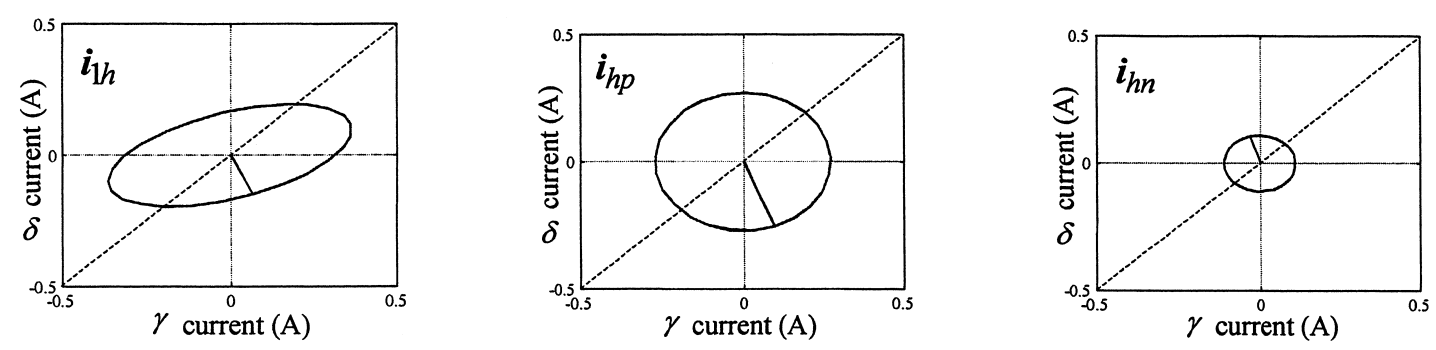

図 $8 K=0.5$, ゼロ速度での高周波電流と正相，逆相成分

Fig. 8. High-frequency current and its positive and negative phase components for $K=0.5$ and zero speed.
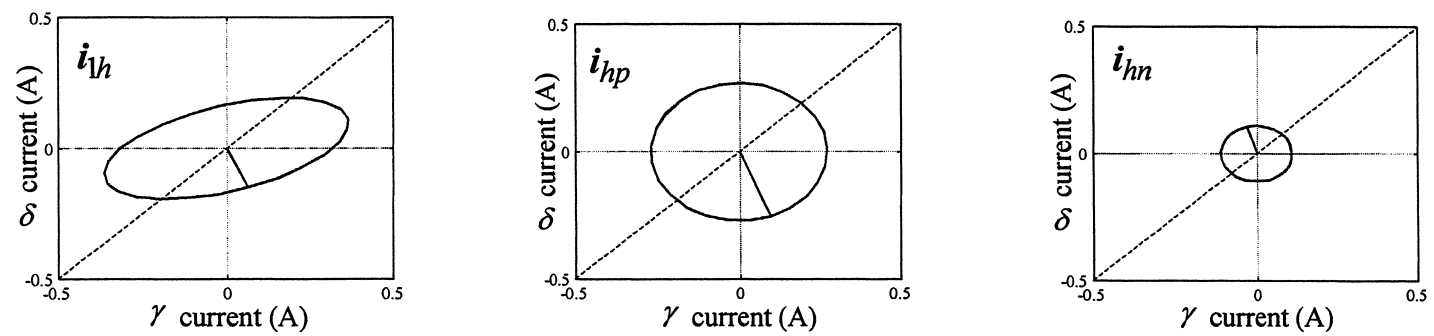

図 $9 K=0.5$, 定格速度での高周波電流と正相，逆相成分

Fig. 9. High-frequency current and its positive and negative phase components for $K=0.5$ and rating speed. 

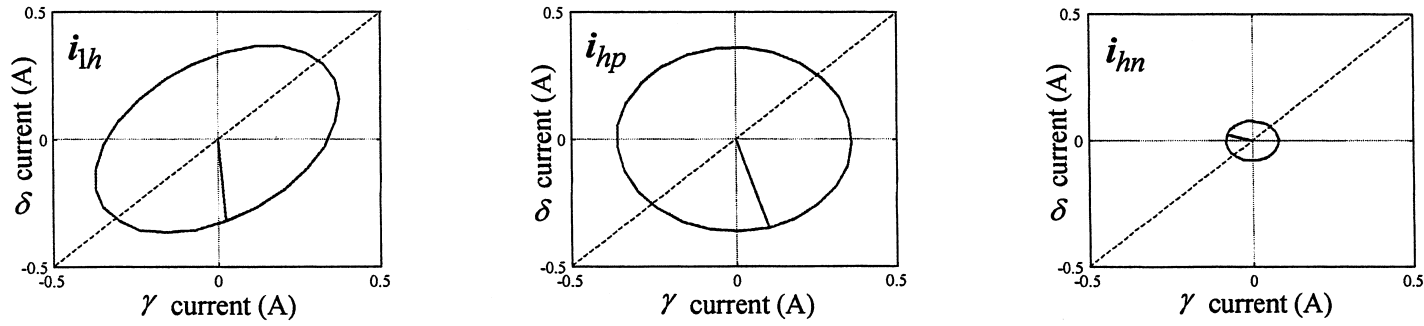

図 $10 K=1$, 定格速度での高周波電流と正相, 逆相成分

Fig. 10. High-frequency current and its positive and negative phase components for $K=1$ and rating speed.
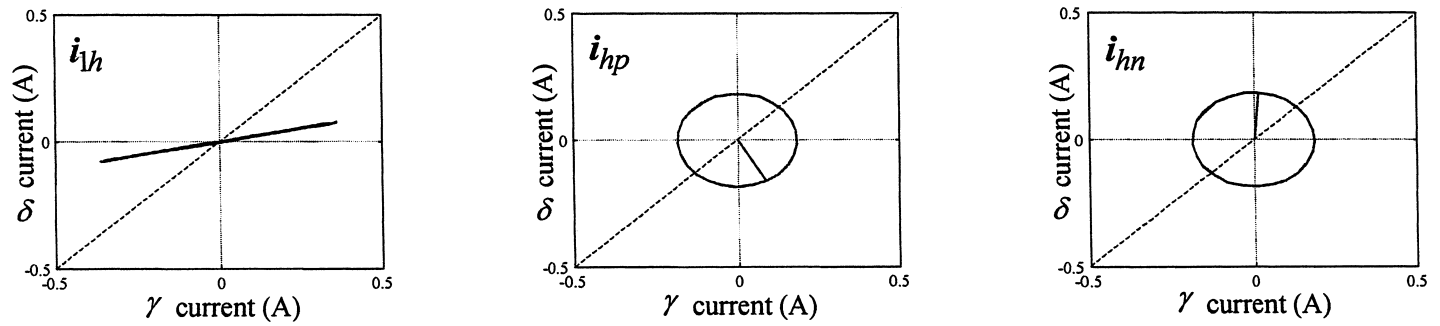

図 $11 K=0$, 定格速度での高周波電流と正相，逆相成分

Fig. 11. High-frequency current and its positive and negative phase components for $K=0$ and rating speed.

\section{B. 位相の正相関と正相逆相成分比の検証}

一般化速応楕円形高周波電圧印加法における高周波電圧 (46) 式を，設計パラメータを $K=1$ と選定して，印加した。 本選定は，速応真円形高周波電圧印加法における高周波電圧 （24）式を採用したことを意味する。印加時のモー夕速度, 座標系の速度は，図 9 と同一の定格速度とした。図 10 に 応答を示す。同図の意味は，図 8, 図 9 と同一である。高 周波電流楕円長軸位相と回転子位相とが同一である点，及 び正相成分と逆相成分の振幅が大きく異なっている点に注 意されたい。本応答は，〈3・2〉節の解析の正当性を裏付け るものである。

一般化速応楕円形高周波電圧印加法における高周波電圧 (6) 式を, 設計パラメータを $K=0$ と選定して, 印加した。 本選定は，速応楕円形高周波電圧印加法における高周波電 圧 (34) 式を採用したことを意味する。印加時のモー夕速 度，座標系の速度は，図 9, 図 10 と同一の定格速度とし た。図 11 に応答を示す。同図の意味は，図 8～図 10 と同 一である。高周波電流の直線軌道の位相が，回転子位相と 大きく乘離している点，これに対して同一振幅の正相成分 と逆相成分が抽出されている点に注意されたい。本応答は, $\langle 3 \cdot 3\rangle$ 節の解析の正当性を裏付けるものである。

設計パラメータ $K=0.5$ の図 $9, K=1$ の図 $10, K=0$ の 図 11 とによる 3 図の応答比較により, 設計パラメータ $K$ を 用いて，回転子位相と高周波電流楕円長軸位相との正相関の 度合い, 正相逆相成分比の調整が可能であるとした の解析結果の正当性が，確認される。

なお，図 8〜図 11 のすべての高周波電流においては，正 相成分と逆相成分を除く，他の成分は一切存在しないこと を確認している。これも, 第 3 章の解析結果と一致する。

\section{5. 汎用位相推定法}

〈5・1〉 位相推定の原理＼cjkstart本節では，一般化速応楕円 形高周波電圧印加法に適用可能な, 回転子位相推定法を提 示する。第 3 章での解析結果より明白なように，更には第 4 章で数值実験を通じ定量的に確認したように，設計パラ メータ $K=1$ の選定以外では, 回転子位相と高周波楕円 長軸位相とは，同一ではない。しかし，設計パラメータ $K$ に依存するが，回転子位相 $\theta_{\gamma}$ と高周波楕円長軸位相 $\theta_{\gamma e}$ と の間に正の相関が維持される正相関領域が存在する（図 3, 図 6 参照)。回転子位相真值が正相関領域に存在し, 高周波 楕円長軸位相が推定できれば，固定座標系の $\alpha$ 軸から評価 した回転子位相 $\theta_{\alpha}$ と速度 $\omega_{2 n}$ とを推定することは可能で ある (図 1 参照)。SP-PMSM のベクトル制御に必要な位相 は， $\alpha$ 軸から評価した回転子位相である。

本論文が，一般化速応楕円形高周波電圧印加法において， すべての設計パラメータ $K$ に対して適用可能な汎用性ある 回転子位相速度推定法として推奨するのは，高周波電流の 正相成分と逆相成分を用いた鏡相推定法である(3)。高周波 楕円長軸位相の特性を解明した定理 5 (長軸位相定理) が 補題 2 (鏡相推定補題) から演繹的に構築されたことより 理解されるように，高周波楕円長軸位相の推定には，補題 2 の利用が合理的である。鏡相推定法は，高周波楕円長軸 位相の推定に補題 2 を利用したものであり，(33) 式が成立 する一定真円形高周波電圧印加法に関連して, 新中により 提案された ${ }^{(3)}$ 。以下に説明するように，(33) 式の条件に代 わって正相関条件を使用すれば，この沉用化が可能である。 鏡相推定法を一般化速応楕円形高周波電圧印加法へ適用 した場合の動作原理は，以下のように整理される。 


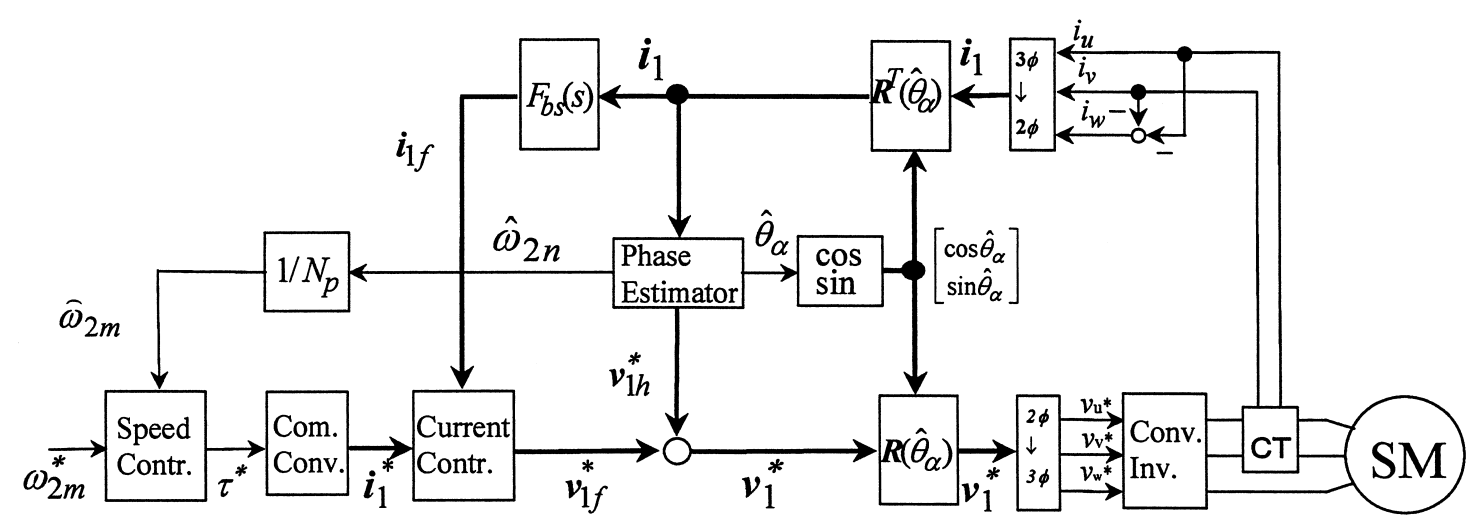

図 12 提案センサレスベクトル制御系の 1 構成例

Fig. 12. A configuration of the proposed sensorless vector control.

(a) 高周波電流楕円長軸位相 $\theta_{\gamma e}$ に対する正相成分と逆相 成分との鏡相特性に従い，これら両成分を用い，高 周波電流楕円長軸位相 $\theta_{\gamma e}$ を推定する（補題 1, 2 参 照) ${ }^{(3)}$ 。

(b) 楕円長軸位相推定值 $\hat{\theta}_{\gamma e}$ を得たならば, $\hat{\theta}_{\gamma e} \rightarrow 0$ とな るように, 固定 $\alpha$ 軸から評価した $\gamma \delta$ 座標系の位相 $(\gamma$ 軸位相と同義）を調整する。

(c) $\gamma \delta$ 座標系の位相調整には，新中によって体系化され た一般化積分形 PLL 法を適用すればよい(3)(19)。これ により， $\gamma \delta$ 座標系の位相と同時に，同座標系の速度 $\omega$ を得る。本座標系速度 $\omega$ は, 回転子速度の推定值 に利用する ${ }^{(3)(19)}$ 。

(d) 正相関領域で $\hat{\theta}_{\gamma e} \rightarrow 0$ の達成は, 正相関により $\hat{\theta}_{\gamma} \rightarrow 0$ を意味する。 $\hat{\theta}_{\gamma} \rightarrow 0$ は， $\gamma$ 軸が回転子位相に収斂し たことを意味し， $\gamma \delta$ 座標系位相が回転子位相推定值 となる(図 3 , 図 6 参照)。

鏡相推定法を，一般化速応楕円形高周波電圧印加法へ適 用する場合の追加的考慮は，正相関に関する (d) 項そのも のであるが，鏡相推定法の実現に際しては，(d) 項は出現し ない。代わって, 鏡相推定法の実行に先立って, 回転位相 $\theta_{\gamma}$ が正相関領域に存在することを確認することが，追加的 に必要となる。なお，鏡相推定法の実現には，高周波電流 の正相成分と逆相成分の分離抽出が不可欠であるが，これ には，D因子フィルタを利用すればよい（後掲の図 14 参 照) ${ }^{(16)(17)}$ 。

\section{$\langle\mathbf{5} \cdot \mathbf{2}\rangle \quad$ システムの構成例}

\section{A. 全系の構成}

活用の便を考慮し，一般化速応楕円形高周波電圧印加法 と鏡相推定法と併用したセンサレスベクトル制御システム の具体的な構成を例示する。図 12 はこの 1 例である。本セ ンサレスベクトル制御システムと位置センサを利用した通 常のベクトル制御システムとの基本的な違いは, dq 座標系 への収斂を目指した $\gamma \delta$ 座標系上の電流情報から回転子の位 相と（電気）速度とを推定する位相推定器（phase estimator と表示）の有無にあり，他は同一である。以下，これらを 順次説明する。

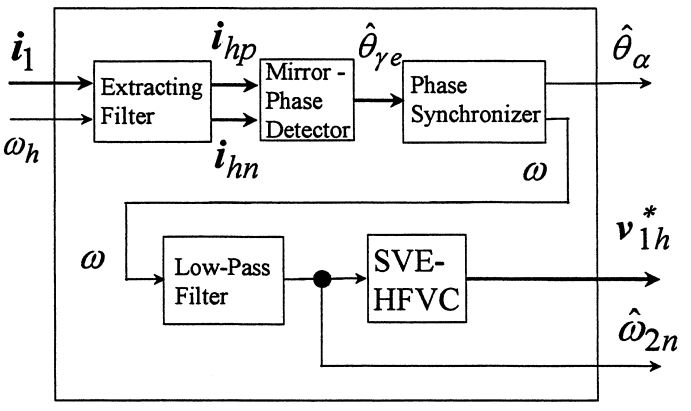

図 13 位相推定器の構造

Fig. 13. A configuration of the phase estimator.

\section{B. 位相推定器の構成}

位相推定器は，本論文が提案した一般化速応楕円形高周 波電圧印加法と再提案した鏡相推定法とを実現したもので, $\gamma \delta$ 座標系上で定義された固定子電流の測定值 $\boldsymbol{i}_{1}$ を入力とし て受け, ベクトル回転器に使用される固定 $\alpha \beta$ 座標系上の回 転子位相推定值 (すなわち, $\gamma \delta$ 同期座標系の位相) $\hat{\theta}_{\alpha}$, 回転 子電気速度の推定值 $\hat{\omega}_{2 n}$, 及び一般化速応棈円形高周波電 圧指令 $\boldsymbol{v}_{1 h}^{*}$ の 3 信号を出力している。本器の構成の 1 例を 図 13 に示した。これは正逆相成分抽出フィルタ (extracting filter と表示)，鏡相検出器 (mirror-phase detector), 位相同 期器 (phase synchronizer と表示), ローパスフィルタ (lowpass filter と表示), 及び速応楕円形高周波電圧指令発生器 (speed-variable-ellipse high-frequency voltage commander, SVE-HFVC と表示) から構成されている。

\section{C. 正逆相成分抽出フィルタ}

正逆相成分抽出フィルタの目的は，高周波電流を含む固 定子電流 $\boldsymbol{i}_{1}$ から, 高周波の正相成分 $\boldsymbol{i}_{h p}$ と逆相成分 $\boldsymbol{i}_{h n}$ の 直接抽出である。これは，2 個の D 因子フィルタを用いて 構成されている ${ }^{(16)(17)}$ 。図 14 に，構成の 1 例を示した。同 図の $\boldsymbol{F}(\boldsymbol{D})$ が D 因子フィルタを意味している。眓より明ら かなように, 正逆相成分抽出フィルタは, 高周波電流 $\boldsymbol{i}_{1 h}$ 自 体を得ることなく，これを含む固定子電流から正相成分と 逆相成分とを直接抽出している。すなわち，鏡相推定法の 実現においては, 高周波電流 $\boldsymbol{i}_{1 h}$ 自体の抽出と言う処理過 


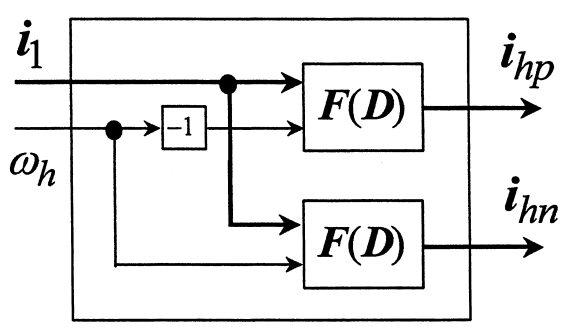

図 14 正逆相成分抽出フィルタの構造

Fig. 14. A configuration of the extracting filter.

程は必要としない。この点には，特に注意されたい

\section{D. 鏡相検出器}

長軸位相推定器の役割は, 高周波電流長軸位相推定值 $\hat{\theta}_{\gamma e}$ の決定にある。これは, 補題 2 (鏡相推定補題), 定理 5 (長 軸位相定理）に従い，高周波電流の正相成分と逆相成分を 用い，以下のように決定している ${ }^{(3)}$ 。

$$
\left.\begin{array}{l}
{\left[\begin{array}{c}
C_{2 p} \\
S_{2 p}
\end{array}\right]=\left[\begin{array}{ll}
\boldsymbol{i}_{h p} & \boldsymbol{J} \boldsymbol{i}_{h p}
\end{array}\right] \boldsymbol{i}_{h n}} \\
\hat{\theta}_{\gamma e}=\frac{1}{2} \tan ^{-1}\left(\frac{S_{2 p}}{C_{2 p}}\right)
\end{array}\right\} .
$$

\section{E. 位相同期器}

位相同期器の役割は，長軸位相推定值 $\hat{\theta}_{\gamma e}$ を用いて $\gamma \delta$ 座 標系の位相 $\hat{\theta}_{\alpha}$ と速度 $\omega$ を決定することである。位相同期器 は, 次の一般化積分形 PLL 法に基づき構成されている ${ }^{(19)}$ 。

$$
\left.\begin{array}{l}
\omega=C_{P L L}(s) \hat{\theta}_{\gamma e} \\
\hat{\theta}_{\alpha}=\frac{1}{s} \omega
\end{array}\right\}
$$

ただし，

$$
\begin{aligned}
C_{P L L}(s) & =\frac{C_{n}(s)}{C_{d}(s)} \\
& =\frac{c_{n m} s^{m}+c_{n m-1} s^{m-1}+\cdots+c_{n 0}}{s^{m}+c_{d m-1} s^{m-1}+\cdots+c_{d 0}} \cdots \cdots
\end{aligned}
$$

上の分子分母多項式 $C_{n}(s), C_{d}(s)$ は，(68) 式で定義された $H(s)$ がフルビッツ (Hurwitz) 多項式となるよう設計すれ ばよい。

$$
H(s)=s C_{d}(s)+C_{n}(s)
$$

\section{F. ローパスフィルタ}

ローパスフィルタの目的は, $\gamma \delta$ 座標系速度に含まれ得る 高調波成分を除去し，回転子の電気速度推定值 $\hat{\omega}_{2 n}$ を生成 することである。フィル夕次数は, 通常は, 1 次でよい。ま た, PLLの帯域が不用意に大きくなければ, 一般に, 本フィ ルタは省略可能である。この場合には, $\hat{\omega}_{2 n}=\omega$ となる。

\section{G. 速応楕円形高周波電圧指令発生器}

SVE-HFVC は，ローパスフィルタから電気速度推定值 $\hat{\omega}_{2 n}$ を受け取り，(46) 式に基づき，速応楕円形高周波電圧 指令值 $\boldsymbol{v}_{1 h}^{*}$ を以下のように生成している。

$$
\boldsymbol{v}_{1 h}^{*}=V_{h}\left[\begin{array}{c}
\left(1+K \frac{\hat{\omega}_{2 n}}{\omega_{h}}\right) \cos \omega_{h} t \\
\left(K+\frac{\hat{\omega}_{2 n}}{\omega_{h}}\right) \sin \omega_{h} t
\end{array}\right] ; \quad \begin{aligned}
& V_{h}=\mathrm{const} \\
& \omega_{h}=\mathrm{const}
\end{aligned}
$$

すなわち，実際的には，高調波成分を含む可能性のある $\gamma \delta$ 座標系の速度 $\omega$ に代わって，これを排除した電気速度推定 值 $\hat{\omega}_{2 n}$ を利用して, 速応楕円形高周波電圧指令值を生成し ている。

\section{6. おわりに}

本論文では，新規な速応振幅高周波電圧印加法として， 一般化速応楕円形高周波電圧印加法を新規提示した。新規 提示に際し，回転子位相の安定推定の観点から，高周波電 流の挙動を新規に解析した。特に, 高周波電流の速度独立 性, 高周波電流を構成する正相成分と逆相成分の比である 正相逆相成分比, 高周波電流棈円の長軸位相と回転子位相 との正相関領域の重要性を指摘し, これらを解析的に明ら かにし，更には数值実験により解析結果の正当性を定量的 に確認した。一般化速応楕円形高周波電圧印加法は, 速度 独立性を有すると共に，正相逆相成分比と正相関領域との 調整能力も有することを示した。一般化速応楕円形高周波 電圧印加法は, 設計パラメータ $K$ により, 速応真円形高周 波電圧印加法から速応楕円形高周波電圧印加法まで変化す る多様性を有するが，これらにすべてに適用可能な汎用位 相推定法として，鏡相推定法が使用できることを新たに示 した。最後に，これらが直ちに活用できるように，この具 体的構成例を示した。

次世代の高周波電圧印加法である速応振幅高周波電圧印 加法は, 研究の途についたばかりである。新規提案の一般 化速応楕円形高周波電圧印加法は, この有力な候補である。 提案法の実機を用いた実験に関しては，稿を改めて報告す る予定である。

(平成 19 年 1 月 5 日受付，平成 19 年 3 月 6 日再受付)

\section{文献}

（1）新中新二：「突極形永久磁石同期モータセンサレス駆動のための速 応楕円形高周波電圧印加法，一高周波電流相関信号を入力とする一 般化積分形 PLL 法による位相検出一」, 平 18 電学全大講演論文集 4, pp.192-193 (2006-3)

(2) S. Shinnaka: "A New High-Frequency Voltage Injection Method for Sensorless Drive of Permanent-Magnet Synchronous Motors with Pole Saliency", IEEJ Trans. IA, Vol.126, No.11, pp.1572-1584 (2006-11) (in Japanese) 新中新二：「突極形永久磁石同期モータセンサレス駆動のための速 応楕円形高周波電圧印加法の提案, 一高周波電流相関信号を入力 とする一般化積分形 PLL 法による位相推定一」, 電学論 D, 126, 11, pp.1572-1584 (2006-11)

(3) S. Shinnaka: "A Mirror-Phase Based Sensorless Control of Salient-Pole PMSM", Trans. of SICE, Vol.40, No.5, pp.536-545 (2004-5) (in Japanese) 新中新二: 「突極形永久磁石同期モータのセンサレス駆動のための 鏡相形ベクトル制御」, 計測自動制御学会論文集, 40, 5, pp.536-545 (2004-5)

(4) M.J. Corley and R.D. Lorenz: "Rotor Position and Velocity Estimation for a Salient-Pole Permanent-Magnet Synchronous Machine at Standstill and High Speed", IEEE Trans. IA, Vol.34, No.4. pp.784-789 (1998-8) 
(5) L. Wang and R.D. Lorenz: "Rotor Position Estimation for PermanentMagnet Synchronous Motor Using Saliency-Tracking Self-Sensing Method", Conference Record of 2000 IEEE IA Conf. (IAS 2000), pp.445-450 (200010)

（6）藍原隆司：「電動機の磁極位置検出装置」, 日本国特許第 3312472 号 (1994-3-1)

( 7 ) T. Aihara, A. Toba, T. Yanase, A. Mashimo, and K. Endo: "Sensorless Torque Control of Salient-Pole Synchronous Motor at Zero-Speed Operation”, IEEE Trans. on Power Electronics, Vol.14, No.1, pp.202-208 (19991)

（8）井手耕三：「同期電動機の磁極位置推定方法および制御装置」, 公開 特許公報, 特開 2002-291283 (2001-3-26)

(9) J.H. Jang, S.K. Sul, J.I. Ha, K. Ide, and M. Sawamura: "Sensorless Drive of SMPM Motor by High-Frequency Signal Injection Based on Magnet Saliency", Proc. of 17th IEEE Applied Power Electronics Conference and Exposition (APEC 2002), Vol.1, pp.279-285 (2002-3)

(10) J. Holtz: "Initial Rotor Polarity Detection and Sensorless Control of PM Synchronous Machines", CD-Conference-Record of 2006 IEEE IA Conf. (IAS 2006) (2006-10)

(11) S. Shinnaka and S. Takeuchi: "Development of a New Sensorless-VectorControlled and Transmissionless Electric Vehicle Using a PermanentMagnet Synchronous Motor", IEEJ Trans. IA, Vol.125, No.12. pp.11291138 (2005-12) (in Japanese)

新中新二・竹内 茂:「永久磁石同期モータを利用したセンサレス ベクトル制御駆動・トランスミッションレス電気自動車の開発」, 電 学論 D, 125, 12, pp.1129-1138 (2005-12)

(12) N. Patel, T. O'Meara, J. Nagashima, and R. Lorenz: "Encoderless IPM traction drive for EV/HEV", CD-Conference-Record of 2001 IEEE IA Conf (IAS 2001) (2001-10)

(13) K. Yasui, Y. Nakazawa, O. Yamazaki, and I. Yasuoka: "Development of Rotor Position Sensorless Control for PRM Applied to Railway Traction Drive", CD-Proc. of 2005 International Power Electronics Conference (IPEC-Niigata 2005) (2005-4)

(14) Y. Nakano, H. Sugiyama, Y. Yamamoto, and T. Ashikaga: "Sensor-less Vector Control System Using Concentrated Winding Permanent Magnet Motor", Proc. of 22nd International Battery, Hybrid and Fuel Cell Electric Vehicle Symposium \& Exposition (EVS22), pp.677-686 (2006-10)

（15）新中新二：「同期モータの統一的ベクトル解析」, 平 9 電学産業応用 部門大会論文集, 2, pp.211-216(1997-8)

(16) S. Shinnaka: "A New Multivariable Filter with Variable-Frequency Characteristics for Three-Phase Signal Processing, - Simple Production of Effects by Filters Accompanies with Vector Rotators-", IEEJ Trans IA, Vol.121, No.2, pp.253-260 (2001-2) (in Japanese)

新中新二：「三相信号処理のための可変特性多変数フィルタの提案, 一ベクトル回転器同伴フィルタ効果の簡易発生一」, 電学論 D, 121, 2 , pp.253-260 (2001-2)

(17) S. Shinnaka: "Characteristics-Varying Systems in the D-Module, -Their Properties on Existence, Realization and Stability-", IEEJ Trans IA, Vol.122, No.6, pp.591-600 (2002-6) (in Japanese) 新中新二: 「可変特性 D 因子システム, 一その存在性, 実現性, 安 定性一」, 電学論 D, 122, 6, pp.591-600 (2002-6)

(18) S. Shinnaka: "New Block Diagrams Using Vector Signals for AC Machine", IEEJ Trans IA, Vol.118, No.6, pp.715-723 (1998-6) (in Japanese) 新中新二：「ベクトル信号を用いた交流回転機のブロック線図」, 電 学論 D, 118, 6, pp.715-723 (1998-6)

(19) S. Shinnaka: "New Sensorless Vector Control Methods Based on a New Minimum-Order Flux State-Observer in the D-module for Permanent
Magnet Synchronous Motors", IEEJ Trans IA, Vol.123, No.12, pp.14461450 (2003-12) (in Japanese)

新中新二：「永久磁石同期モータの最小次元 D 因子状態オブザーバ とこれを用いたセンサレスベクトル制御法の提案」,電学論 D, 123, 12, pp.1446-1450 (2003-12)

(20) N. Nomura, A. Toba, T. Yamasaki, S. Ozaki, and H. Osawa: "PositionSensorless Drive of the Interior Permanent Magnet Synchronous Motor for Wide Speed Range", CD-Proc. of 9th European Conference on Power Electronics and Applications (EPE2001) (2001-8)

(21) R. Masaki, S. Kaneko, Y. Sakurai, and M. Honbu: "Position Sensorless Control System of IPM Motor Based on Voltage Injection Synchronized with PWM Carrier", IEEJ Trans. IA, Vol.122, No.1, pp.37-43 (2002-1) (in Japanese)

正木良三・金子 悟・櫻井芳美・本部光幸：「搬送波に同期した電圧 重畳に基づくIPM モータの位置センサレス制御システム」, 電学論 D, 122, 1, pp.37-43 (2002-1)

(22) R. Masaki, S. Kaneko, M. Hombu, T. Sawada, and S. Yoshihara: "Development of a Position Sensorless Control System on an Electric Vehicle Driven by a Permanent Magnet Synchronous Motor", Proc. of Power Conversion Conference-Osaka (PCC-Osaka 2002), pp.571-576 (2002-4)

新 中 新 二 (正員) 1973 年防衛大学校卒業。同年陸上自衛

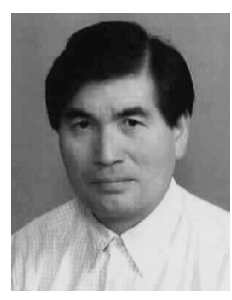
隊中央野外通信群入隊。1977 年 University of California，Irvine 大学院修士課程修了。1979 年同博 士課程修了。防衛庁技術研究本部第 1 研究所, 防 衛大学校電気工学教室等での奉職を終えて，1986 年陸上自衛隊を除隊。同年キヤノン（株）勤務。 1991 年ベンチャー研究所創設。1996 年神奈川大 学電気工学科勤務 (教授, 現電子情報フロンティ ア学科)。2002 年同学市民 EV センター創設 (代表)。これまでの間, 通信, 情報, 制御, パワーエレクトロニクス分野の教育, 研究, 開発 及びこれらの管理等に従事。近年はサーボモータ駆動制御技術の体 系化に専念し，2001 年に誘導モータを用いたセンサレスベクトル制 御駆動・トランスミッションレス電気自動車 (ST-EV) の世界初開発 に成功。本功績により 2002 年計測自動制御学会より技術賞を受賞。 2003 年 IEEE IAS-Transactions 論文賞受賞。2004 年永久磁石同期モー 夕を用いた ST-EV の世界初開発に成功。同期モータセンサレス駆動制 御における周波数ハイブリッド基本概念（日本国特許第 3612636 号, 1996.9.18)，ミール法基本概念 (日本国特許第 3735836 号, 2000.1.2, 第 3814826 号，2004.12.10), 最小次元磁束状態オブザーバ基本概念（日 本国特許第 3653670 号，2002.8.31），鏡相推定基本概念（日本国特許 第 3328636 号, 2000.3.17, 第 3968688 号, 2000.11.28, 第 3968689 号, 2000.12.23）等を含む多くの基本技術の第 1 提唱者。計測自動制御学 会，IEEE，欧州 EPE，自動車技術会などの会員。Doctor of Philosophy 及び工学博士。 